\title{
Experimental Models to Study Autism Spectrum Disorders: hiPSCs, Rodents and Zebrafish
}

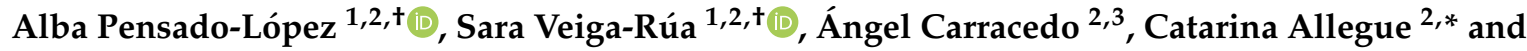 \\ Laura Sánchez ${ }^{1, * \mathbb{D}}$ \\ 1 Department of Zoology, Genetics and Physical Anthropology, Universidade de Santiago de Compostela, \\ Campus de Lugo, 27002 Lugo, Spain; alba.pensado.lopez@rai.usc.es (A.P.-L.); \\ sara.veiga.rua@rai.usc.es (S.V.-R.) \\ 2 Genomic Medicine Group, Center for Research in Molecular Medicine and Chronic Diseases (CiMUS), \\ Universidade de Santiago de Compostela, 15706 Santiago de Compostela, Spain; angel.carracedo@usc.es \\ 3 Centro de Investigación Biomédica en Red de Enfermedades Raras (CIBERER), CIMUS, \\ Universidade de Santiago de Compostela, 15706 Santiago de Compostela, Spain \\ * Correspondence: catarina.allegue@usc.es (C.A.); lauraelena.sanchez@usc.es (L.S.) \\ + These authors contributed equally to this work.
}

Received: 9 October 2020; Accepted: 18 November 2020; Published: 20 November 2020

check for updates

\begin{abstract}
Autism Spectrum Disorders (ASD) affect around 1.5\% of the global population, which manifest alterations in communication and socialization, as well as repetitive behaviors or restricted interests. ASD is a complex disorder with known environmental and genetic contributors; however, ASD etiology is far from being clear. In the past decades, many efforts have been put into developing new models to study ASD, both in vitro and in vivo. These models have a lot of potential to help to validate some of the previously associated risk factors to the development of the disorder, and to test new potential therapies that help to alleviate ASD symptoms. The present review is focused on the recent advances towards the generation of models for the study of ASD, which would be a useful tool to decipher the bases of the disorder, as well as to conduct drug screenings that hopefully lead to the identification of useful compounds to help patients deal with the symptoms of ASD.
\end{abstract}

Keywords: autism spectrum disorders (ASD); animal models; cellular models; genome editing; human induced pluripotent stem cells (hiPSCs); neurodevelopmental disorders (NDDs); rodents; zebrafish

\section{Introduction}

\subsection{Definition and Epidemiology of Autism Spectrum Disorders}

Autism Spectrum Disorders (ASD)-affected individuals are characterized by the presence of social and communication impairments and the lack of common skills in developing, maintaining, and understanding relationships. In addition to these symptoms, patients might also develop stereotyped or repetitive patterns of behavior, interests and/or activities. According to the 5th edition of the Diagnostic and Statistical Manual of Mental Disorders (DSM-5), the ASD category includes the following neurodevelopmental disorders (NDDs): early infantile autism, childhood autism, Kanner's autism, high functioning autism, atypical autism, pervasive developmental disorder not otherwise specified (PDD-NOS), childhood disintegrative disorder, and Asperger's disorder [1].

The prevalence of ASD is estimated to be around 1.5\% [2-4], although these data vary depending on the year and the country dataset consulted (Figure 1). Differences among datasets could be associated with real differences on ASD prevalence, but also with errors due to diagnostic difficulties or lack of trustworthy data [5]. 


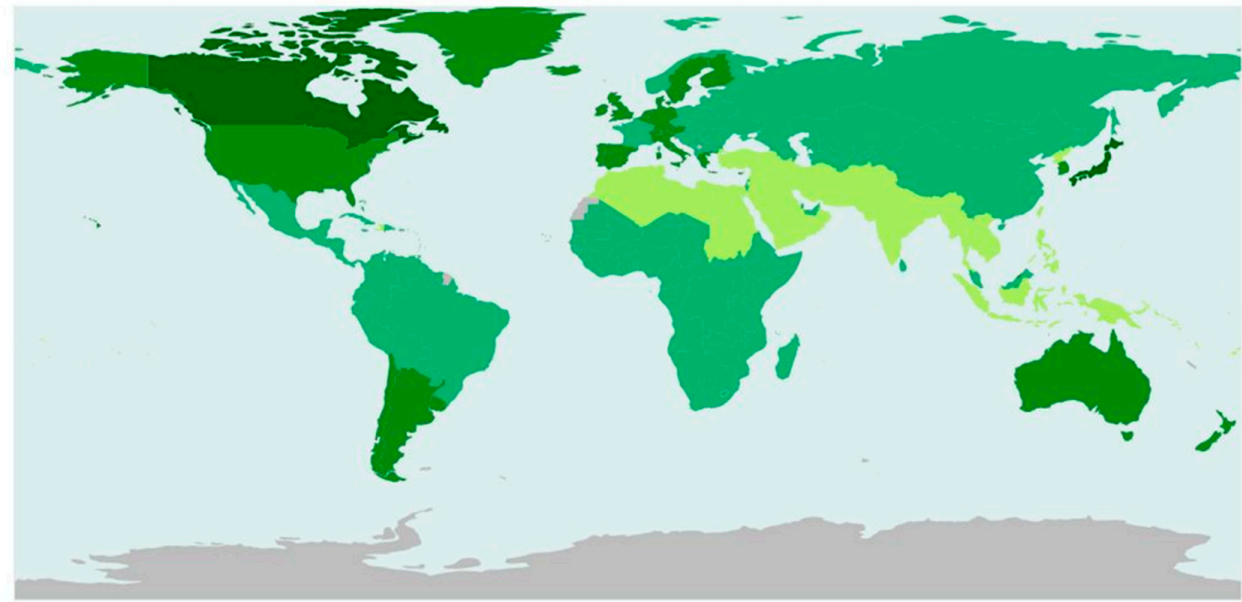

\section{$0 \%-0.4 \% \square 0.4 \%-0.6 \% \square 0.6 \%-0.8 \% \square 0.8 \%-1 \%$}

Figure 1. Map of the prevalence of Autism Spectrum Disorders (ASD) around the world in 2017. Light green: prevalence between $0-0.4 \%$; blue: prevalence between $0.4-0.6 \%$; green: prevalence between $0.6-0.8 \%$; dark green: prevalence between $0.8-1 \%$. Countries from which no data are available are plotted in grey. The figure was elaborated using R software (R Core Team, Vienna, Austria) to represent open access data which have been previously standardized to age and sex $[2,4,6]$.

\subsection{Aetiology of Autism Spectrum Disorders}

Depending on whether the origin of ASD is known or not, the disorder can be classified into two subgroups: syndromic and non-syndromic ASD. Syndromic ASD includes those cases with a well-characterized etiology, whereas non-syndromic ASD cases have a less defined etiology, with multiple factors contributing to the development of the disorder [7].

ASD can be linked to prenatal, perinatal and postnatal risk factors, which can be either genetic or environmental [8]. Several environmental factors have been found strongly correlated with ASD development, such as advanced parental age, pregnancy and birth complications, vitamin D deficiency and heavy metal exposition [8-10].

Regarding genetics, their relevance in ASD risk development has been known for over 50 years, mainly due to the results observed in twin studies. The first twin studies indicated that ASD concordance could be around $\sim 90 \%$ in monozygotic twins, in comparison with a $30 \%$ concordance observed in dizygotic twins [11-13]. However, recent data seem to indicate that ASD concordance in monozygotic twins might be lower $(\sim 50 \%)$ [10].

Despite the obvious challenges associated with the identification of ASD causes, many susceptibility genes have been identified by genetic analysis, including exome sequencing and genome-wide association studies (GWAS). ASD-associated genes are frequently involved in the regulation of neural and synaptic development and its alteration can lead to dysfunctions in brain areas that regulate high cognitive functions [13-16]. In addition, molecular alterations in excitatory cortical neurons, microglia and cortico-cortical projection neurons have also been associated with ASD severity [17].

Both common and rare genetic variants have been associated with ASD development. Available data suggest that de novo mutations in coding regions are among the most frequent variants associated with ASD. However, other genetic alterations such as copy number variations (CNVs) and chromosomal alterations have also been associated with the development of the disorder $[7,13,18,19]$.

One of the most complete recompilation of ASD-associated genes is the SFARI Gene Database [20,21]. In the 2020 database release, genes are classified according to a gene score $(1,2$ or 3$)$ that takes into account the amount of information supporting the implication of a certain gene in ASD development. Genes with score 1 are high confidence ASD-associated genes with a minimum of three de novo disrupting mutations linked in patients to the development of the disorder. Genes with score 2 are 
strong candidates with two de novo disrupting mutations associated with ASD development. Finally, genes with score 3 are those with one reported de novo disrupting mutation linked to ASD, but the results have not been replicated yet.

A total of 913 genes have been registered into the SFARI Gene Database (https://gene.sfari.org/, latest release 2020) as ASD-associated genes with their corresponding score following the previously mentioned criteria (Figure 2a) [20,21]. These genes are not evenly distributed throughout the genome, for instance, high confidence ASD-associated genes (gene score 1) are particularly abundant in the chromosome X (Figure 2b,c). Some authors have linked this observation with the male-to-female ASD ratio which is about 4 to $1[11,22]$.

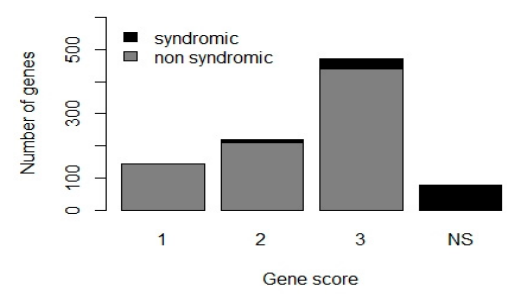

(a)

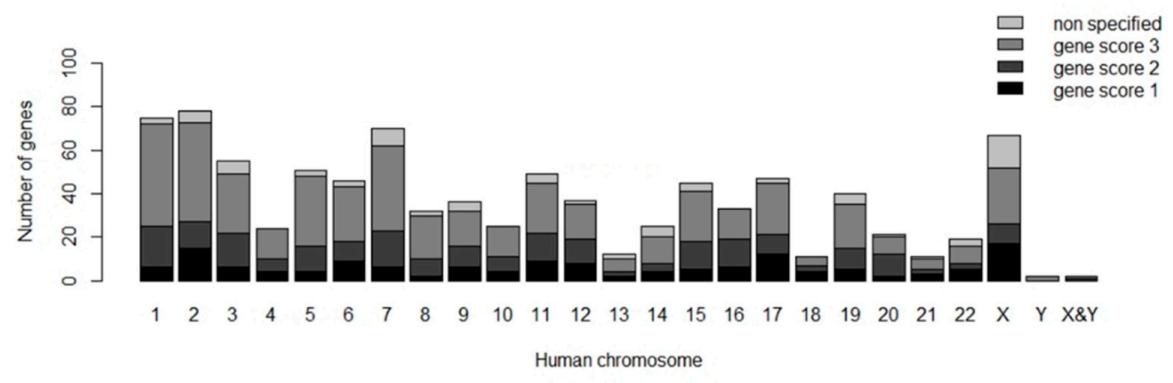

(b)

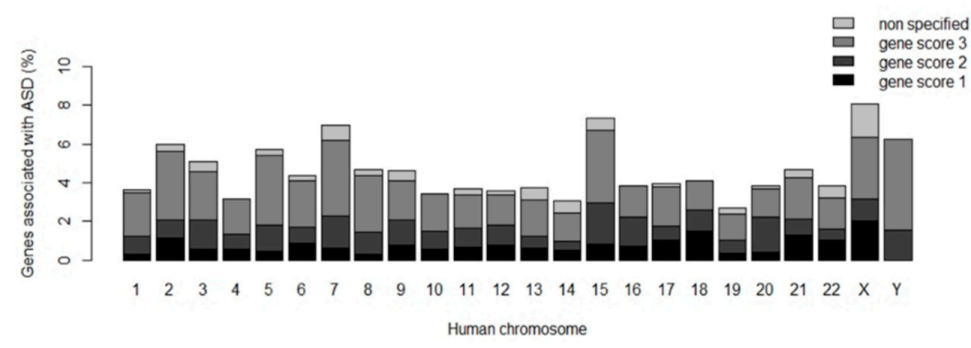

(c)

Figure 2. Human ASD-associated genes according to the SFARI Gene Database (2020). Gene score 1: high confidence genes with a minimum of three de novo likely gene disrupting mutations associated to ASD. Gene score 2: strong candidate genes with two de novo gene-disrupting mutations associated to ASD. Gene score 3: suggestive evidence of the association of the gene with ASD development, due to one reported de novo likely gene-disrupting mutation. (a) Classification of the 913 ASD-associated genes in the SFARI Gene Database according to the gene score and their presence in syndromic or non-syndromic ASD patients (NS = non-specified); (b) ASD-associated genes distribution in the human genome; (c) Percentage of ASD-associated genes identified on each human chromosome. The figure was elaborated using open-access data from SFARI Gene Database (obtained in January 2020) and R software $[6,20,21]$. 


\title{
1.3. Diagnostic of Autism Spectrum Disorders
}

Nowadays, ASD diagnosis is based on standard clinical criteria (Table 1) that evaluate the symptoms and their severity in each case [1]. However, ASD symptoms can vary a lot between individuals. In the most severe cases, an accurate diagnosis is usually made at an early age (1-2\% of the population), but milder phenotypes can be harder to identify for clinicians, as different NDDs can co-occur and symptoms might be very similar $[1,7,23]$.

Table 1. Standard clinical criteria for the identification and diagnosis of ASD in the population according to the DSM-5 [1].

\section{Clinical Diagnosis Criteria for ASD}

Deficits in social communication and interaction

Restricted and repetitive patterns of behavior, interests, or activities

Symptoms present during early development

Presence of impairments in important areas of an individual's functioning

Symptoms are not better explained by other mental disorder

\begin{abstract}
ASD: Autism Spectrum Disorders; DSM-5: the 5th edition of the Diagnostic and Statistical Manual of
\end{abstract} Mental Disorders.

The current approach to diagnose and treat ASD patients is far from optimal. To improve this situation, it is essential to broaden the current knowledge of ASD bases, which could give us new insights to improve the diagnosis and treatment of patients.

\subsection{Treatment of Autism Spectrum Disorders}

Treatment for ASD patients is essentially focused on ameliorating the symptoms of the disorder to reduce the impact it has on the daily activities of the affected individuals. To this end, it is frequent that patients receive a combination of therapeutic approaches, including behavioral therapy and/or medication (see Table 2 for a list of ASD-related therapies). There is no medication that can completely alleviate ASD symptoms or cure the disorder. However, some compounds-such as $\alpha 2$-adrenergic agonists and olanzapine-have been approved to ameliorate some symptoms of the disorder, but their efficiency is limited [24,25]. 
Table 2. Therapeutic options available to treat ASD symptoms. Available therapeutic approaches can be classified into three groups: psychosocial therapies, pharmacology and complementary alternative medicine. In the table below, it can be found a list of the available therapies divided into these three categories, including a brief explanation on which ASD symptoms can be ameliorated by their use, as well as their previously reported side effects [24,25].

\begin{tabular}{|c|c|c|c|c|}
\hline Type of Therapy & Therapy & Procedure & Areas with Improvement & Side Effects \\
\hline \multirow[t]{4}{*}{ Psychosocial therapies } & Applied behavior analysis (ABA) & $\begin{array}{l}\text { Repetition of learning trials (positive } \\
\text { reinforcement) }\end{array}$ & $\begin{array}{l}\text { Intellectual functioning, language, daily } \\
\text { living skills and socialization }\end{array}$ & $\begin{array}{c}\text { Long-term and costly therapy, need } \\
\text { patient's cooperation and } \\
\text { motivation }\end{array}$ \\
\hline & Pivotal Response Treatment (PRT) & Targets specific skills and motivations & $\begin{array}{l}\text { Improve communication skills and less } \\
\text { disruptive behaviors compared to ABA }\end{array}$ & No significant side effects \\
\hline & Parent-mediated early interventions & $\begin{array}{l}\text { Interventions that can be applied at } \\
\text { home by parents }\end{array}$ & Socialization and communication & No significant side effects \\
\hline & Social skills interventions & Interventions to improve social skills & $\begin{array}{l}\text { Emotional regulation, communication } \\
\text { and socialization }\end{array}$ & No significant side effects \\
\hline \multirow[t]{12}{*}{ Pharmacology } & Risperidone & Atypical Antipsychotics & $\begin{array}{l}\text { Irritability, socialization and } \\
\text { communication }\end{array}$ & $\begin{array}{l}\text { Weight gain, increased appetite and } \\
\text { somnolence }\end{array}$ \\
\hline & $\begin{array}{l}\text { Aripiprazole } \\
\text { Olanzapine }\end{array}$ & $\begin{array}{l}\text { Atypical Antipsychotics } \\
\text { Atypical Antipsychotics }\end{array}$ & $\begin{array}{l}\text { Irritability } \\
\text { Irritability }\end{array}$ & $\begin{array}{l}\text { Weight gain and somnolence } \\
\text { Weight gain }\end{array}$ \\
\hline & Ziprasidone & Atypical Antipsychotics & Irritability & $\begin{array}{l}\text { Cardiovascular alterations and } \\
\text { somnolence }\end{array}$ \\
\hline & Paliperidone & Atypical Antipsychotics & Irritability & $\begin{array}{l}\text { Weight gain and extrapyramidal } \\
\text { symptoms }\end{array}$ \\
\hline & Haloperidol & Typical Antipsychotics & $\begin{array}{l}\text { Hyperactivity, stereotypical behaviors } \\
\text { and learning on discrimination tasks }\end{array}$ & $\begin{array}{l}\text { Somnolence, irritability and } \\
\text { dystonic reactions }\end{array}$ \\
\hline & Antidepressants: venlafaxine & Typical Antipsychotics & $\begin{array}{l}\text { Repetitive behaviors, socialization and } \\
\text { communication }\end{array}$ & $\begin{array}{l}\text { Hyperactivity, inattention, nausea } \\
\text { and polyuria }\end{array}$ \\
\hline & Antidepressants: clomipramine & Typical Antipsychotics & $\begin{array}{c}\text { Stereotypical behavior and anger } \\
\text { management }\end{array}$ & No significant side effects \\
\hline & Divalproex sodium & Mood stabilizers & Irritability and repetitive behaviors & No significant side effects \\
\hline & Methylphenidate & Stimulants/atomoxetine $/ \alpha-2$ agonists & Hyperactivity & $\begin{array}{l}\text { Appetite decrease, insomnia, } \\
\text { irritability and emotional outbursts }\end{array}$ \\
\hline & Atomoxetine & Stimulants/atomoxetine $/ \alpha-2$ agonists & Hyperactivity and impulsivity & No significant side effects \\
\hline & $\begin{array}{l}\alpha-2 \text { agonists: clonidine and } \\
\text { guanfacine }\end{array}$ & Stimulants/atomoxetine $/ \alpha-2$ agonists & Hyperactivity & Somnolence \\
\hline & Naltrexone & Other medications & Hyperactivity and impulsivity & No significant side effects \\
\hline $\begin{array}{l}\text { Complementary alternative } \\
\text { medicine }\end{array}$ & Melatonin & & Sleep disturbances & No significant side effects \\
\hline
\end{tabular}




\section{Genome Editing Systems, a Promising Tool for Modeling Human Disorders}

As mentioned before, both genetic and environmental risk factors contribute to ASD development. Due to this complexity, deciphering the individual impact of each risk factor on the development of ASD was a difficult task for researchers for a long time, and it is still a challenge.

This scenario recently changed due to the development of improved genetic edition systems which allow simplifying the study of the function of selected genes and their relationship with disease-related phenotypes. To date, there are three main types of genetic editing systems available: Zinc Finger Nucleases (ZFNs), Transcription Activator-Like Effector Nucleases (TALENs) and CRISPR/Cas (Clustered Regularly Interspaced Short Palindromic Repeats). The first editing tools available were ZFNs, in 1996 [26] and TALENs, in 2010 [27], both based on the recognition between a DNA sequence and a protein. A new editing system based on DNA-RNA recognition was developed in 2013, which received the name of CRISPR/Cas [28]. This technology supposed a revolution in the field of genome editing, which is now accessible to almost every laboratory worldwide.

The increased accessibility of CRISPR/Cas system makes it a powerful tool in many research areas, from agriculture to ecological vector control or biomedicine. To the purpose of the present review, it is especially interesting to mention the broad applications of CRISPR/Cas system in biomedical research, ranging from targeted genome editing to the regulation of gene expression or even the labeling of endogenous sequences. This technology has a great potential to generate pre-clinical models of many human disorders, both in vitro and in vivo, that could help to understand the molecular pathways that lead to the development of a certain pathology [29-31].

\section{Fundamentals of Genomic Editing}

All three systems (Figure 3) create specific breaks into the DNA, which in turn trigger the cellular DNA repair mechanisms. Eukaryotic cells have two main routes of DNA repair: non-homologous end joining (NHEJ) and homology-directed repair (HDR). NHEJ pathway is faster, but also prone to error, generating insertions or deletions (indels) due to its activity. NHEJ often alters gene's reading frame or inserts stop codons at unusual places, generating truncated proteins that are unable to properly function. HDR pathway is more precise as it can correct alterations using a donor sequence as a template. Taking advantage of the HDR system allows the introduction of specific modifications in the genome, which can be as small as one single nucleotide [32].

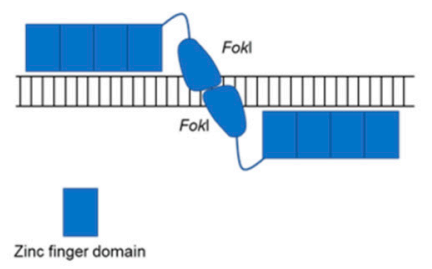

(a)

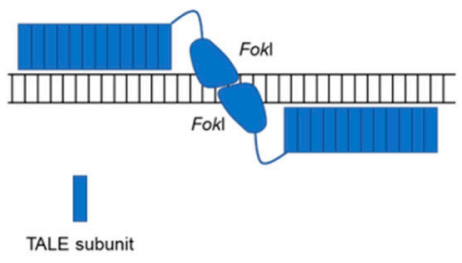

(b)

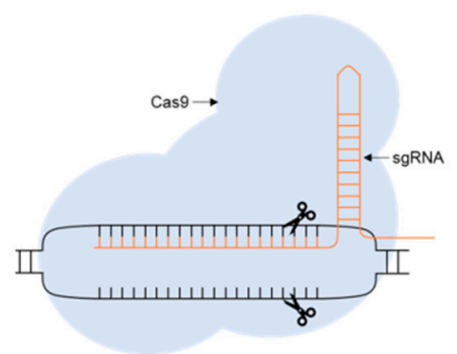

(c)

Figure 3. The main genomic editing systems available at the moment. (a) Zinc Finger Nucleases-ZFNs: two zinc finger nucleases act as a dimer, each one harboring a DNA binding domain and a DNA cleaving domain FokI; (b) Transcription Activator-Like Effector Nucleases-TALENs: TALENs act as a dimer, each one harboring a DNA binding domain (TAL effectors) and a DNA cleaving domain FokI; (c) CRISPR/Cas9: a sgRNA binds to the DNA and to the Cas9 endonuclease, facilitating the creation of double-strand breaks (DSBs) in the DNA. The image is original and was created by the authors of the present review.

ZFNs are a type of DNA-binding proteins that can be used to create double-strand breaks (DSBs) at desired positions in the genome. To function, this edition system requires two zinc finger nucleases, 
each one harboring two essential domains: a DNA binding domain and a DNA cleaving domain. The DNA binding domain is composed of protein modules, each one able to recognize a specific nucleotide triplet. The second essential domain of a ZFN is the sequence-independent cleaving domain, which is derived from the endonuclease FokI (Figure 3a). The combination of both domains allows the ZFN to act as a site-specific nuclease [26,33]. ZFNs are an efficient editing system that can be applied to multiple experimental models, including cell cultures and animal models [34-37]. However, despite their efficiency, the use of ZFNs has not been widespread due to the difficulty of the experimental design and the required validation.

TALENs emerged in 2010 as an alternative to ZFNs. TALENs function is based on the combination of FokI cleavage activity and transcription activator-like effectors (TALEs) (Figure 3b) which target individual base pairs. In comparison with ZFNs, TALENs are easier to synthesize, but the required protein design is still challenging [27,38].

As mentioned above, the most recently developed genomic editing system was CRISPR/Cas9 which is based on bacterial immune systems CRISPR type II. In comparison with ZFN and TALENs, CRISPR/Cas9 stands out for its relative simplicity, as it only needs two elements to function. The first one is the Cas9 nuclease, which contains two endonuclease domains, HNH and RuvC-like, which create DSBs in the DNA. The other essential element of this system is the single guide (sgRNA), which is composed of two regions: trans-activating CRISPR RNA (tracrRNA) and CRISPR RNA (crRNA). The tracrRNA, allows the binding between the Cas9 nuclease and the guide itself, whereas the crRNA is fundamental for the recognition of a specific target site in the genome (Figure 3c) [28-31].

The original model has been modified over the years, introducing modifications and improvements in its functioning. Nowadays, Cas 9 can be substituted by other enzymes, expanding the applications of the technique.

CRISPR/Cas immune systems have been found in a wide range of prokaryotes, both bacteria and archaea. This indicates that there might be a broad number of Cas-like proteins that remain undiscovered to date, which could have new characteristics and/or properties of interest for genetic engineering purposes [39]. Some of them have already been characterized such as Cas13 family members, which are able to introduce breaks into RNA, opening the possibility of mRNA manipulation using the CRISPR system [40,41].

New types of Cas nucleases could be useful in order to broaden our battery of CRISPR/Cas modifying enzymes, but the possibility of engineering known nucleases, such as Cas9, is also interesting. For instance, a lot of effort has been put into the development of inducible forms of Cas9, as well as into altering its recognition site (PAM sequence) and improving its fidelity [42,43]. In addition, it is also intriguing the development of versions of Cas9 with one (Cas9 nickases, nCas9) or two (dead Cas9, dCas9) non-active catalytic domains. These modified Cas9s can be in turn fused with other enzymatic domains, which is the functional base of CRISPR interference (CRISPRi) [44], CRISPR activation (CRISPRa) [45], base editing [46] and prime editing [47].

One important drawback of CRISPR/Cas technology is the presence of off-target effects in the genome of the edited cells, which can be especially dangerous for clinical applications. Notwithstanding, there are mechanisms that can help to evaluate the occurrence of non-specific effects, such as whole-exome sequencing (WES) or whole-genome sequencing (WGS), although the latter generates a huge amount of data to be analyzed and biologically interpreted. Remarkably, the results of the studies carried to date seem to indicate that the occurrence of off-targets is, in fact, similar to the normal mutation rate of cells [48,49].

Genetic edition by CRISPR/Cas system has been applied successfully on many model organisms, including Caenorhabditis elegans [50], Drosophila melanogaster [51], zebrafish [52], rodents [53], and even primates [54]. CRISPR/Cas has also been used in human cell cultures, both of somatic [28] and embryonic cell lines [55]. 
Both the introduction of indels (knockout, $\mathrm{KO}$ ) and specific genetic modifications (knock-in, $\mathrm{KI}$ ) can be a powerful tool to model gene-base disorders, as it allows researchers to precisely study the association between genes or genetic variants and the development of an altered phenotype.

\section{In Vitro Models of ASD: The Stem Cell Revolution}

Cellular models are very useful for studying diseases with an important genetic contribution, especially if these diseases cause alterations in cell types easy to maintain in the laboratory. As it was previously mentioned, ASD often has a strong genetic component, and its effects are primarily seen on cells of the central nervous system associated with high cognitive functions. These cell types cannot be obtained from biopsies, which supposes an obstacle for the study of ASD bases using cell cultures as a model. In addition, neurons are a highly specialized cell type with a low proliferation rate, so they cannot be cultured for the long term, and thus, model cell lines are hard to establish [7,56,57].

However, this scenario changed in 2006, when Yamanaka and his collaborators identified mechanisms that allow reprogramming adult somatic cells representing new perspectives in molecular biology and biomedicine. These techniques allow the transformation of differentiated cell lines into induced pluripotent stem cells (hiPSCs) by expressing four genes, known as the Yamanaka factors (Oct3/4, Sox2, Klf4, c-Myc) [58]. The main advantages of hiPSCs are their self-renewal capability and their differentiation potential. A new and exciting possibility for the study of neurodevelopmental disorders was then born, as hiPSCs can afterwards be differentiated into cell types from the nervous system. The development of novel reprogramming methods and differentiation protocols makes it now possible to generate cell lines directly from patients, obtaining, as a result, specialized in vitro models to study the cause of the disorder in a particular individual [57,59].

Cellular models directly derived from patients have several advantages in comparison with other in vitro models, such as embryonic cell lines. With this approximation, models for disorders caused by rare variations can be created, which is the case for ASD (Table 3). Cellular models obtained from patients have proven to be highly robust, reliable and realistic, conserving the genetic background of the source. As they match the genetic background of the patients, the biological base of their respective disorders can be analyzed. An additional advantage of these cellular models is that they can be used to revert potentially pathogenic genetic variants, which can help to validate the association between the detected genotype and an altered phenotype $[57,59,60]$.

Cell lines obtained from patients are versatile models, in which analyses to establish the cell and molecular mechanism implied in the curse of the disorder, can be conducted. When addressing neurological disorders, it is possible to study alterations in neuronal morphology, synaptic transmission, cell migration and differentiation capability, among others [56,59,60].

These models are useful to establish a relationship between a genotype and a phenotype, but also to develop new therapeutic approaches, including cell therapy and pharmacological treatments. This can be achieved by studies for the identification of new therapeutic targets or biomarkers, as well as drug sensibility assays, which are helpful to validate the action of the selected drugs prior to clinical assays [57,59].

For all the stated reasons, this approach opens new possibilities for the study of the molecular bases of complex disorders, such as ASD. Several research groups have been working in this field to study both syndromic and non-syndromic forms of ASD. In Table 3, a list of ASD-associated genes that have been studied using this approach can be found. Some long non-coding RNAs (lncRNAs), such as PTCHD1-AS or COSMOC [61,62] are also included. Further information about recent studies that implicate lncRNAs, other non-coding mutations, and regulatory variants in ASD susceptibility can be found in the excellent review by Ross et al. [63].

Despite the advantages of in vitro models, it is undeniable that cell culture cannot fully recapitulate all the complexity behind the development of ASD, for this reason, animal models are still a fundamental tool to fully understand them. 
Table 3. Types of alterations observed in neural-like cell lines with a lack of expression of ASD-associated genes. Neural-like cell lines developed to study ASD have been obtained by the differentiation of human induced pluripotent stem cells (hiPSCs) from patients or by the inactivation of the selected ASD-associated gene in controls, using genomic editing systems.

\begin{tabular}{|c|c|c|c|}
\hline $\begin{array}{l}\text { Cell Lines Derived from } \\
\text { hiPSCs }\end{array}$ & ASD-Associated Gene & Alterations Due to the Lack of Expression of ASD-Associated Gene & References \\
\hline \multirow{14}{*}{ Cortical neurons } & & Reduced neurite length and complexity & \\
\hline & & Altered neuronal activity & \\
\hline & ЕНМТ1 & Increased expression of proliferation genes & [64] \\
\hline & & Decreased expression of maturation and migration genes & \\
\hline & МЕСР2 & Increased synaptogenesis and dendritic complexity & [65] \\
\hline & IVILCPZ & Altered neuronal network synchronization & {$[00]$} \\
\hline & NRXN1 & Altered ion transport and calcium signaling & [66] \\
\hline & PTCHD1 & $\begin{array}{l}\text { Decreased frequency of miniature excitatory postsynaptic currents } \\
\text { N-methyl-D-aspartate receptor (NMDARs) hypofunction }\end{array}$ & {$[61]$} \\
\hline & PTCHD1-AS & $\begin{array}{l}\text { Decreased frequency of miniature excitatory postsynaptic currents } \\
\text { Increased number of synapses, dendritic length and complexity }\end{array}$ & [61] \\
\hline & SHANK2 & $\begin{array}{c}\text { Increased frequency of spontaneous excitatory postsynaptic currents } \\
\text { Altered expression of genes associated to neuronal morphogenesis, plasticity } \\
\text { and synapse }\end{array}$ & [67] \\
\hline & SHANK3 & Synaptic alteration and decreased dendritic spines & {$[68,69]$} \\
\hline & & Mitochondria disorganization and altered mitophagy & \\
\hline & TSC2 & $\begin{array}{l}\text { Increased soma size and neurite number } \\
\text { mTORC1 signaling pathway hyperactivation }\end{array}$ & {$[70,71]$} \\
\hline & & Increased neuronal activity and upregulation of cell adhesion genes & \\
\hline Dopaminergic neurons & RELN & Altered neuronal migration & [72] \\
\hline \multirow[t]{6}{*}{ Glutamatergic neurons } & AFF2 & $\begin{array}{l}\text { Alteration in genes associated with neuronal development } \\
\text { Decreased synaptic activity: reduced spontaneous excitatory postsynaptic currents }\end{array}$ & [73] \\
\hline & ASTN2 & $\begin{array}{l}\text { Alteration in genes associated with neuronal development } \\
\text { Decreased synaptic activity: reduced spontaneous excitatory postsynaptic currents }\end{array}$ & [73] \\
\hline & ATRX & $\begin{array}{l}\text { Alteration in genes associated with neuronal development } \\
\text { Decreased synaptic activity: reduced spontaneous excitatory postsynaptic currents }\end{array}$ & [73] \\
\hline & CNTN5 & Increased neuronal activity & [74] \\
\hline & KCNQ2 & Decreased synaptic activity: reduced spontaneous excitatory postsynaptic currents & [73] \\
\hline & $S C N 2 A$ & $\begin{array}{l}\text { Alteration in genes associated with morphogenesis } \\
\text { Decreased synaptic activity: reduced spontaneous excitatory postsynaptic currents }\end{array}$ & [73] \\
\hline
\end{tabular}


Table 3. Cont.

\begin{tabular}{|c|c|c|c|}
\hline $\begin{array}{l}\text { Cell Lines Derived from } \\
\text { hiPSCs }\end{array}$ & ASD-Associated Gene & Alterations Due to the Lack of Expression of ASD-Associated Gene & References \\
\hline \multirow[t]{14}{*}{ Neuron-like cells } & ARHGEF9 & Altered mTORC1 signaling pathway & [75] \\
\hline & & Altered calcium signaling & \\
\hline & CACNA1C & Altered differentiation of neurons from cortical layers & \\
\hline & CACNAIC & Increased production of norepinephrine and dopamine & {$[76,77]$} \\
\hline & & Altered expression of tyrosine hydrolase & \\
\hline & CDKL5 & Alterations in neuronal activity & [78] \\
\hline & CHD8 & $\begin{array}{l}\text { Altered expression of genes associated with neural development, } \beta \text {-catenin/Wnt } \\
\text { signaling, extracellular matrix and skeletal svstem development }\end{array}$ & [79] \\
\hline & COSMOC & Impaired redox homeostasis & \\
\hline & COSMOC & Altered PTBP2 splicing & [62] \\
\hline & & Altered DNA methylation patterns & \\
\hline & $F M R 1$ & $\begin{array}{l}\text { Altered expression of genes associated with neuronal development, migration and } \\
\text { maturation }\end{array}$ & [80-82] \\
\hline & & Altered neurite formation and neuronal differentiation & \\
\hline & SHANK3 & $\begin{array}{c}\text { Alterations in the soma and neurites, as well as alterations in synaptic transmission } \\
\text { Altered expression of genes associated to motility and neurogenesis }\end{array}$ & {$[83,84]$} \\
\hline & TRPC6 & $\begin{array}{l}\text { Reduce neurite length and complexity } \\
\text { Altered glutamatergic synapse formation and reduced sodium influx }\end{array}$ & [85] \\
\hline Neural organoids & CHD8 & $\begin{array}{c}\text { Alterations in the expression of gens associated with neurogenesis, } \beta \text {-catenin/Wnt } \\
\text { signaling, neuronal differentiation and axonal guidance }\end{array}$ & [86] \\
\hline \multirow{4}{*}{ Neural progenitor cells } & NRXN1 & Alterations in neuronal adhesion and differentiation & {$[87,88]$} \\
\hline & RELN & Overactivation of mTORC1 pathway & [89] \\
\hline & TRPC6 & $\begin{array}{c}\text { Altered calcium signaling and expression of genes involved in cell adhesion and } \\
\text { neurite formation }\end{array}$ & [85] \\
\hline & ZNF804A & Altered expression of pathways mediated by interferon- $\alpha 2$ & [90] \\
\hline Olfactory placodal neurons & SHANK3 & Decreased number of synapses & [91] \\
\hline & S11R11VN & $\begin{array}{l}\text { Alterations during neural development in the soma and neurites } \\
\text { Hypoexcitability and synaptic dysfunction }\end{array}$ & [91] \\
\hline \multirow[t]{2}{*}{ Purkinje cells } & TSC2 & mTORC1 pathway hyperactivation & [92] \\
\hline & & Altered neuronal differentiation & \\
\hline
\end{tabular}




\section{Animal Models in ASD Research}

Traditionally, animal models have been used to study the complex background of ASD, as it was not possible to establish human neuronal cell cultures with an unlimited proliferation capability. Animal models are especially useful for studying disorders of the central nervous system because they help to validate the implication of selected genes in the curse of the disorder.

For an organism to be an adequate model for any human disease or disorder, including ASD, it should have the following characteristics: strong analogies to human phenotype (Table 4); the same biological alteration that causes the human disease; and analogous response to treatments that could ameliorate the human disease or disorder [7,93-95].

Two main approaches have been used to identify animal models for ASD. The first approach is forward genetics, in which ASD-like phenotypes are identified in the selected animal model, and then the molecular bases of the observed alterations are elucidated. The second approach is reverse genetics, in which targeted mutations are introduced into the genome of the animal model, and then the phenotype is characterized [96].

Rodents are the most used animal models in neuroscience research, being Mus musculus the most frequent one. This does not mean that mice are better models than other species, but it has more to do with a practical issue: the mouse genome was sequenced first and tools to manipulate it were developed faster. Nevertheless, nowadays, this information and tools are available for a wide range of model organisms, some of them with a lot of potential in ASD modeling, such as Rattus norvegicus or Danio rerio. This means that new animal models to study ASD might be developed in the near future [96-99].

Table 4. Assays to evaluate the presence of ASD-like alterations in model organisms (rodents and zebrafish). The behavioral assays are focused on detecting alterations in the three core areas affected in ASD-patients: socialization, non-social patterns of behavior (including repetitive behavior, motor alterations and limited range of activities) and communication [93,98,99].

\begin{tabular}{|c|c|c|}
\hline Areas of Interest & Behavioral Assays in Rodents & Behavioral Assays in Zebrafish \\
\hline Socialization & $\begin{array}{l}\text { - Social approach task: time spent with an } \\
\text { unknown individual compared to a new } \\
\text { non-social object } \\
\text { - Social preference tests (affiliation and } \\
\text { recognition): time expend with an unknown } \\
\text { animal in comparison with a familiar one } \\
\text { - Free interaction test: time spent interacting } \\
\text { with unknown individuals compared to the } \\
\text { time spent doing other activities } \\
\text { (e.g., exploring) } \\
\text { Social interactions: presence of interactions } \\
\text { such as sniffing, following, pushing each } \\
\text { other, etc. }\end{array}$ & $\begin{array}{l}\text { - S Preference for } \\
\text { - } \quad \text { Shonspecific individuals. } \\
\text { natation distance between } \\
\text { individuals (nearest neighbor } \\
\text { distance, farthest neighbor distance, } \\
\text { average inter-individual distance, } \\
\text { time spent inside the shoal and } \\
\text { polarization). } \\
\text { Social interactions: presence of } \\
\text { behaviors such as approaching, } \\
\text { circling, mouth opening, biting, } \\
\text { chasing, etc. }\end{array}$ \\
\hline $\begin{array}{c}\text { Non-social patterns } \\
\text { of behavior }\end{array}$ & $\begin{array}{l}\text { - Open field test: presence and duration of } \\
\text { spontaneous motor stereotypies. } \\
\text { Reversal learning tasks: these tests evaluate } \\
\text { the capability of the individual to habituate to } \\
\text { a new routine. A routine should be established } \\
\text { for the animals (acquisition phase) before a } \\
\text { new one is introduced (reversal phase). } \\
\text { - Range of interests: measure of the exploratory } \\
\text { activity of the subject animal. } \\
\text { Burying behavior: presence of } \\
\text { digging behaviors. }\end{array}$ & $\begin{array}{l}\text { - Repetitive behavior: presence of } \\
\text { repetitive patterns of } \\
\text { locomotor activity. } \\
\text { Inhibitory avoidance response: a } \\
\text { two-chamber tank is set up, with one } \\
\text { chamber harboring an attractive } \\
\text { stimulus paired with and aversive } \\
\text { response. The latency of the } \\
\text { individuals to enter the chamber } \\
\text { harboring the aversive response } \\
\text { is measured. }\end{array}$ \\
\hline
\end{tabular}


Table 4. Cont.

\begin{tabular}{lll}
\hline \multicolumn{1}{c}{ Areas of Interest } & \multicolumn{1}{c}{ Behavioral Assays in Rodents } & Behavioral Assays in Zebrafish \\
\hline & $\quad \begin{array}{l}\text { Ultrasonic vocalizations (USV): reduced levels } \\
\text { of USVs or non-usual patterns of acoustic } \\
\text { communication have been observed in models } \\
\text { for ASD, as well as altered patterns of response } \\
\text { to them. }\end{array}$ \\
& $\begin{array}{l}\text { Habituation and dishabituation to social odors: } \\
\text { response to a change in a familiar odor for a } \\
\text { new one. }\end{array}$ \\
\hline
\end{tabular}

\subsection{Rodents and the Modelling of Human Disorders}

Rodents have several characteristics that explain why they have been so widely used to model human disorders. First, they have a short generation time and, due to their small size and their social behavior, they can be easily maintained in an animal facility in the laboratory. Additionally, their genome has been sequenced, revealing a high similarity with humans. In addition to this, tools to modify the genomes of both species have been developed, as well as neurological, behavioral (Table 4) and pharmacological assays to evaluate the presence of ASD-like alterations [53,98].

It is undeniable that central nervous system organization is more complex in humans than in rodents. This complexity is reflected not only in the number of regions present in the brain, but also in the number of cells and connections, as well as their diversity. These differences are translated into cognitive and behavioral differences, so it is very unlikely that a rodent model can fully recapitulate the phenotype observed in ASD patients. However, pathways involved in ASD development can be studied in rodent models by using gene editing technologies which lead to the development of animals with phenotypes similar to the observed in humans [7,94]. Although both Mus musculus and Rattus norvegicus are rodents and as such share some common characteristics, there are also key differences between them in terms of physiology, behavior and pharmacological response that affect the type of information that can be obtained from each one.

In terms of physiology, there is a clear difference in body size and weight between both species. The small size of mice can be useful in drug development assays as a lower dose is needed to treat the animal. However, the bigger size of the rats can be an advantage if brain surgery is necessary or if imaging techniques are used, but it also increases the housing costs.

Concerning neurophysiology, some differences are notorious between mice and rat brains. First, it has been shown that some neurotransmitters and their receptors have different distributions on both species. Second, it also has been observed that both species have differences in their neurogenesis, affecting regions such as the hippocampus or the cortical regions, which have been associated with ASD development [97,98].

In terms of pharmacology, proteins derived from mice and rats are highly similar, but key substitutions in important regions to ligand binding have been identified. Is important to acknowledge these differences, especially when using these models to identify potential new drugs for ASD treatment, as they might not perform equally in humans $[97,98]$.

With reference to behavior, both species live in hierarchical groups with complex social interactions, but the interaction between individuals is quite different in both cases. Mice are more territorial and aggressive than rats, but also less impulsive. There are also differences in their cognitive capacities, as rats are easier to train and perform more stably over time, not being as altered by the human presence as mice [97].

Regarding communication, both species have acoustic (USVs) and olfactory signals (pheromones) to transmit messages to conspecifics, but these are slightly more rich in $R$. norvegicus, with both adults and pups emitting a wider range of sounds in different types of situations, from isolation to play [98].

Rodents have been a fundamental preclinical tool to clarify the complex etiology of ASD, as well as to test new potential treatments before clinical trials. One of the reasons for such success is that they 
can recapitulate the core symptoms of ASD: impairments in social interaction, communication and presence of repetitive behaviors $[94,98]$.

\subsubsection{Mus Musculus in ASD Research}

Certain mouse strains with ASD-like phenotypes have arisen due to inbreeding procedures, for example, BTBR $\mathrm{T}+\mathrm{tf} / \mathrm{J}$ strain. This strain is very interesting as it recapitulates many of the human ASD-symptoms, such as social behavior impairments (reduced interaction between individuals, aversion for frontal interaction, etc.), communication impairments (altered patterns or responses to both USV and scent marking) and repetitive behaviors (increase in self-grooming, burying behaviors and preferences for certain objects or spaces). BTBR mice also develop difficulties in learning-related tasks and higher levels of anxiety in the presence of a menace. At the molecular level, this strain shows alterations in the development of the brain, which are also present in humans with ASD. Several ASD-linked genes have been identified to be disrupted in BTBR mice, such as kynurenine 3-hydroxylase, a protein involved in neuroprotection and dopamine signaling, Disc1, and Ext1, a protein involved in the synthesis of guidance molecules [94,100]. However, the majority of ASD relevant mouse models available to date have been generated using reverse genetics, by altering the orthologous ASD-linked genes in the mouse genome. Nowadays, there are nearly 200 mouse models (Figure 4) developed to study such genes, which can be found on SFARI GENE Database [20,21]. Examples of M. musculus models for ASD-candidate genes can be found in Table 5.

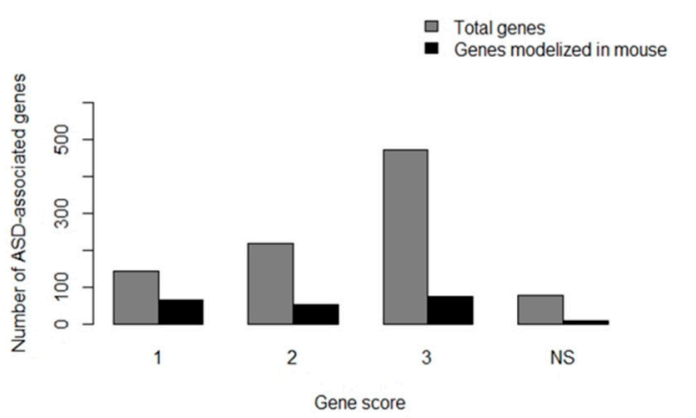

(a)

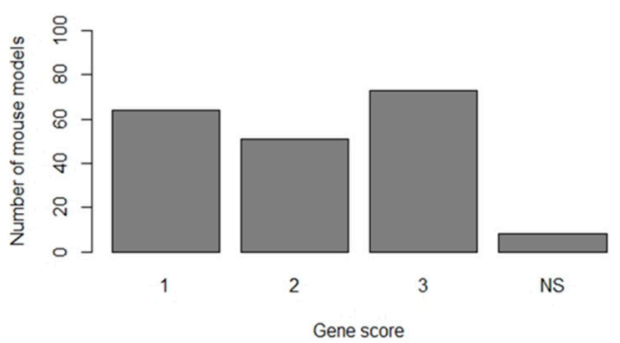

(b)

Figure 4. Mus musculus models developed to study ASD-associated genes. (a) Comparison between the human ASD-associated genes deposited in the SFARI Gene Database, and the number of ASD-associated genes modeled in Mus musculus. Genes are classified according to their SFARI gene score (NS = non-specified); (b) Number of mouse models developed to study ASD-associated genes, classified according to the SFARI gene score (NS = non-specified). The figure was elaborated using open-access data from SFARI Gene Database (obtained in January 2020) and R software [6,20,21].

\subsubsection{Rattus norvegicus in ASD Research}

Due to their more complex behavior and social interactions, rats have been postulated as a model organism with high potential to study NDDs, including ASD.

The first rat KO models available to study ASD were generated in 2010 using ZFN and ENU induced mutagenesis [98]. Nowadays, the number of available rat models has increased, including genetic models for certain ASD-risk genes (Table 6), and some pharmacological rescue models.

Nevertheless, despite the obvious suitability of rodent models for ASD modeling and the invaluable information they offer, there are still some noticeable drawbacks that have led researchers to opt for more manageable models, such as zebrafish. 
Table 5. Phenotype observed in Mus musculus models of ASD-associated genes. The table includes the some of the developed models to study the function and implication in ASD of genes classified with score 1 (high confidence) or gene score 2 (strong candidate) in the SFARI Gene database [20,21]. In the cases in which several models have been developed, the phenotype column only includes their common characteristics; LOF—loss of function, SVZ—subventricular zone, MGE—-medial ganglionic eminence, $\mathrm{KO}-$ knockout.

\begin{tabular}{|c|c|c|c|}
\hline ASD-Associated Gene/Mus musculus & Gene Modification Technique & Main Phenotypical Observations & Reference \\
\hline ADNP/Adnp & KO by homologous recombination & $\begin{array}{c}\text { Embryonic lethality }(\mathrm{KO}) \\
\text { Developmental delay } \\
\text { Decreased neuronal survival } \\
\text { Social and memory impairments }\end{array}$ & [101-103] \\
\hline ARID1B/Arid1b & $\begin{array}{c}\text { KO by CRISPR/Cas } 9 \\
\text { Conditional heterozygous KO by Cas } 9 \\
\text { (floxed allele) }\end{array}$ & $\begin{array}{c}\text { Increased lethality } \\
\text { Abnormal brain and heart development } \\
\text { Decreased neuronal precursor proliferation and cortical thickness } \\
\text { Anxiety and social interaction alterations } \\
\text { Decreased cognitive flexibility }\end{array}$ & {$[104,105]$} \\
\hline ASH1L/Ash1l & $\begin{array}{l}\text { KO with gene trap vector, piggyBac or } \\
\text { CRISPR/Cas9 }\end{array}$ & $\begin{array}{l}\text { Increased lethality and infertility } \\
\text { Delayed eye development } \\
\text { Reduced adiposity } \\
\text { Altered immune response } \\
\text { Reduced chromatin modification }\end{array}$ & [106-108] \\
\hline CHD2/Chd2 & $\begin{array}{c}\text { Targeted KO with cassette } \\
\text { Cre-flox } \\
\text { Conditional LOF in interneurons }\end{array}$ & $\begin{array}{c}\text { Growth delay and increased mortality } \\
\text { Abnormal synaptic transmission } \\
\text { Reduced number of neural precursors and interneurons } \\
\text { Altered hippocampal morphology } \\
\text { Decreased object recognition memory } \\
\text { Decreased spatial working memory }\end{array}$ & {$[109,110]$} \\
\hline CHD8/Chd8 & $\begin{array}{c}\text { Knockdown (shRNAs) } \\
\text { KO by CRISPR/Cas9 or Cre-LoxP }\end{array}$ & $\begin{array}{c}\text { Altered brain development, corticogenesis and differentiation of } \\
\text { neural precursors } \\
\text { Reduced density of the dendritic tree } \\
\text { Decreased myelination } \\
\text { Increased anxiety and altered sociability } \\
\text { Increased repetitive behaviors } \\
\text { Altered memory patterns }\end{array}$ & [111-118] \\
\hline $\mathrm{CIC} / \mathrm{Cic}$ & $\begin{array}{l}\text { Conditional LOF in the neocortex, } \\
\text { hippocampus and pallium }\end{array}$ & $\begin{array}{c}\text { Altered hippocampal and cortical morphology } \\
\text { Reduced number of postmitotic excitatory neurons of the forebrain } \\
\text { Reduced dendritic complexity } \\
\text { Reduced social interactions }\end{array}$ & [119] \\
\hline
\end{tabular}


Table 5. Cont.

\begin{tabular}{|c|c|c|c|}
\hline ASD-Associated Gene/Mus musculus & Gene Modification Technique & Main Phenotypical Observations & Reference \\
\hline CNTNAP2/Cntnap2 & Targeted $\mathrm{KO}$ by gene replacement & $\begin{array}{l}\text { Delayed growth } \\
\text { Cortical disorganization in the brain } \\
\text { Decreased levels of neuroreceptors } \\
\text { Repetitive behaviors and seizures } \\
\text { Impairments in social interactions }\end{array}$ & [120-125] \\
\hline GABRB3/Gabrb3 & $\begin{array}{c}\text { Conditional LOF in endothelial cells } \\
\text { Targeted KO }\end{array}$ & $\begin{array}{c}\text { Altered brain morphology } \\
\text { Reduced number of interneurons } \\
\text { Reduced neuronal migration } \\
\text { Decreased levels of GABA neurotransmitter } \\
\text { Increased seizures, anxiety and depression } \\
\text { Reduced social and tactile memory }\end{array}$ & [126-130] \\
\hline PTEN/Pten & $\begin{array}{l}\text { Conditional LOF in: forebrain gabaergic } \\
\text { and dopaminergic neurons; secondary } \\
\text { progenitors in the subpallium SVZ; } \\
\text { Purkinje cells; dentate gyrus, } \\
\text { hippocampus, cortex or ventricular zone } \\
\text { of the MGE }\end{array}$ & $\begin{array}{c}\text { Increased lethality } \\
\text { Altered brain morphology } \\
\text { Reduced number of interneurons } \\
\text { Increased neuronal size and connectivity } \\
\text { Impaired neuronal differentiation } \\
\text { Altered synaptic function } \\
\text { Increased apoptosis in brain cells } \\
\text { Increased thickness in the cerebellum } \\
\text { Decreased number of Purkinje cells } \\
\text { Reduced coordination } \\
\text { Reduced social memory }\end{array}$ & [131-137] \\
\hline RELN/Reln & Spontaneous mutation & $\begin{array}{c}\text { Altered morphology of the brain, cerebellum, cortex and } \\
\text { olfactory bulb } \\
\text { Reduced number of Purkinje cells } \\
\text { Altered neuronal migration patterns } \\
\text { Altered metabolism of neurotransmitters } \\
\text { Impaired coordination } \\
\text { Increased anxiety response levels }\end{array}$ & [138-140] \\
\hline$S C N 2 A / S c n 2 a$ & $\begin{array}{c}\text { Targeted KO by gene interruption } \\
\text { Conditional LOF in dorsal telencephalic } \\
\text { excitatory neurons }\end{array}$ & $\begin{array}{l}\text { Increased apoptosis and mortality } \\
\text { Seizures and hyperactivity } \\
\text { Increased rearing } \\
\text { Reduced anxiety responses }\end{array}$ & [141-143] \\
\hline
\end{tabular}


Table 5. Cont.

\begin{tabular}{|c|c|c|c|}
\hline ASD-Associated Gene/Mus musculus & Gene Modification Technique & Main Phenotypical Observations & Reference \\
\hline SHANK2/Shank2 & $\begin{array}{c}\text { Conditional LOF in Purkinje cells } \\
\text { Targeted KO }\end{array}$ & $\begin{array}{c}\text { Altered synaptic currents } \\
\text { Increased anxiety and hyperactivity } \\
\text { Reduced coordination } \\
\text { Increased repetitive behaviors } \\
\text { Reduced social approach } \\
\text { Decreased spatial learning and memory }\end{array}$ & [144-148] \\
\hline TAOK2/Taok2 & Targeted KO by Cre-LoxP & $\begin{array}{c}\text { Abnormal brain morphology and spine density } \\
\text { Reduced dendritic length and complexity } \\
\text { Reduced cortical lamination and thickness } \\
\text { Impaired memory of context }\end{array}$ & [149] \\
\hline TBR1/Tbr1 & $\begin{array}{c}\text { Conditional LOF in neurons of cortical } \\
\text { layer } 6 \text { and subplate } \\
\text { Targeted KO by homologous } \\
\text { recombination }\end{array}$ & $\begin{array}{c}\text { Altered brain morphology } \\
\text { Reduced neuronal connectivity } \\
\text { Reduced number of interneurons } \\
\text { Altered differentiation of brain cells } \\
\text { Altered cortical organization } \\
\text { Altered synaptic currents } \\
\text { Increased anxiety aggressiveness } \\
\text { Increased aggressive }\end{array}$ & {$[146,150-153]$} \\
\hline UРF3B/Upf3b & Targeted $\mathrm{KO}$ by gene trap & $\begin{array}{c}\text { Reduced spine density } \\
\text { Altered morphology of cortical neurons } \\
\text { Poor differentiation of neural progenitors } \\
\text { Impaired sensorimotor gating } \\
\text { Abnormal clasping reflex } \\
\text { Abnormal sleep pattern } \\
\text { Impaired startle response to acoustic stimuli }\end{array}$ & [154] \\
\hline
\end{tabular}


Table 6. Phenotype observed in Rattus norvegicus models of ASD-associated genes. The table includes the developed models to study the function and implication in ASD of genes classified with score 1 (high confidence) or gene score 2 (strong candidate) in the SFARI Gene database [20,21]. In the cases in which several models have been developed, the phenotype column only includes their common characteristics.

\begin{tabular}{|c|c|c|c|}
\hline ASD-Associated Gene/Rattus norvegicus & Gene Modification Technique & Main Phenotypical Observations & Reference \\
\hline$B C K D K / B c k d k$ & KO by spontaneous mutation & $\begin{array}{c}\text { Neuronal alterations } \\
\text { Reduced protein phosphorylation } \\
\text { Infertility } \\
\text { Altered development }\end{array}$ & [155] \\
\hline CACNA1C/Cacna1c & KO by ZFN & $\begin{array}{l}\text { Altered social behavior and reduced USVs } \\
\text { Increased perseverative behaviors }\end{array}$ & {$[156,157]$} \\
\hline CNTNAP2/Cntnap2 & KO by ZFN & $\begin{array}{c}\text { Seizures } \\
\text { Hyperactivity } \\
\text { Altered audition and sleep routines }\end{array}$ & {$[158,159]$} \\
\hline CYFIP1/Cyfip1 & KO by CRISPR/Cas9 & $\begin{array}{c}\text { Neuronal alterations } \\
\text { Altered behavioral flexibility in learning tasks }\end{array}$ & [160] \\
\hline FMR1/Fmr1 & KO by ZFN & $\begin{array}{c}\text { Increased repetitive behaviors and social alterations. } \\
\text { Altered sensorimotor gating } \\
\text { Memory difficulties } \\
\text { Neuronal alterations } \\
\text { Altered auditory responses }\end{array}$ & [161-163] \\
\hline $\begin{array}{l}\text { MECP2/Mecp2 } \\
\text { NLGN2/Nlgn2 }\end{array}$ & $\begin{array}{c}\text { KO by ZFN } \\
\text { Overexpression in the hippocampus }\end{array}$ & $\begin{array}{c}\text { High mortality } \\
\text { Malocclusion } \\
\text { Neuronal alterations } \\
\text { Hypoactivity } \\
\text { Altered social interaction and speech responses. } \\
\text { Memory alterations } \\
\text { Decreased grip strength } \\
\text { Decreased response to new stimuli and aggressive behavior }\end{array}$ & {$[164,165]$} \\
\hline NLGN3/Nlgn3 & KO by ZFN & $\begin{array}{c}\text { Increased repetitive behaviors } \\
\text { Hyperactivity and altered sleep routines } \\
\text { Decreased body weight } \\
\text { Altered juvenile play behavior and startle response } \\
\text { Altered sensorimotor gating }\end{array}$ & {$[162,167]$} \\
\hline NRXN1/Nrxn1 & KO by biallelic deletion & $\begin{array}{l}\text { Hyperactivity } \\
\text { Altered startle response } \\
\text { Memory alterations }\end{array}$ & [168] \\
\hline
\end{tabular}


Table 6. Cont.

\begin{tabular}{|c|c|c|c|}
\hline ASD-Associated Gene/Rattus norvegicus & Gene Modification Technique & Main Phenotypical Observations & Reference \\
\hline PTEN/Pten & Heterozygous KO by ZFN & Neuronal alterations & [169] \\
\hline$S C N 1 A / \operatorname{Scn} 1 a$ & KO by ENU mutagenesis & $\begin{array}{l}\text { Increased repetitive behaviors } \\
\text { Hyperactivity and anxiety } \\
\text { Learning and memory difficulties } \\
\text { Motor alterations } \\
\text { Reduced dopamine levels }\end{array}$ & [170] \\
\hline SHANK2/Shank2 & KO by ZFN & $\begin{array}{c}\text { Alterations in social behavior } \\
\text { Hyperactivity and increased repetitive behavior } \\
\text { Memory alterations } \\
\text { Neuronal alterations }\end{array}$ & {$[171]$} \\
\hline SHANK3/Shank3 & KO by ZFN & $\begin{array}{l}\text { Alterations in social behavior } \\
\text { Neuronal alterations }\end{array}$ & [172] \\
\hline TCF4/Tcf4 & $\begin{array}{l}\text { KO by CRISPR/Cas9 and knockdown by } \\
\text { shRNA in the prefrontal cortex }\end{array}$ & Altered electrophysiological properties in neurons & [173] \\
\hline TSC2/Tsc2 & KO by spontaneous mutation & $\begin{array}{c}\text { Enhanced episodic-like memory } \\
\text { Enhanced seizure-induced plasticity } \\
\text { Increased induction of phospho-p42-MAPK in the } \\
\text { hippocampus } \\
\text { Increased basal oxygen consumption in the brain }\end{array}$ & {$[174,175]$} \\
\hline UВEЗА/Ube3a & KO by CRISPR/Cas9 & Motor, learning and memory difficulties & [176] \\
\hline
\end{tabular}




\subsection{Zebrafish and the Modeling of Human Disorders}

In recent years, the zebrafish has been postulated as an ideal animal model for the study of the genetic background of several human diseases and remarkably, more than 800 laboratories around the world use nowadays zebrafish as a model [177]. The introduction of the zebrafish as an animal model dates back to the early 1960s, initially used to study vertebrate development and genetics [178]. Since then, researchers have progressively drawn on this animal in several human scientific fields, from genetic diseases, regeneration pathways or toxicology assays to high-throughput drug screenings [179].

Zebrafish is a freshwater fish, native from the streams of the south-eastern Himalayan region, and it owns its name due to its fusiform morphology and the horizontal stripes on each side of the body. There is a notorious sexual dimorphism, which allows the distinction between males and females [180]. Although this fish is able to survive in a range of temperatures from $12^{\circ} \mathrm{C}$ to $39^{\circ} \mathrm{C}$ in nature, its optimal temperature in controlled conditions is $28.5^{\circ} \mathrm{C}$ [181,182]. The biological features that help to explain its use in laboratories, as well as its success as a translational model in biomedical research, in particular in neurosciences $[96,99,183]$, have been increasingly listed since the 1990s [178]. It is worth highlighting the frequent reproduction (once a week), producing between 200 and 400 embryos per couple, enabling the performance of high-throughput assays. The external fertilization and optical transparency of embryos and larvae allow researchers to easily manipulate animals and observe their development, specifically imaging of neurodevelopmental processes and neural activity, even at a single-cell level without using invasive techniques [179]. In addition, zebrafish nearly completes basic development within $24 \mathrm{~h}$, has rapid growth and sexual maturation (3-5 months), and interestingly, zebrafish has delayed development of the adaptive immune system (10-14 days), which is the main basis of its use in cancer research, and possesses an extraordinary tissue regeneration ability [184-186]. Furthermore, there are some other practical issues that make zebrafish stand out when compared with rodents, such as the relatively easy and cost-effective maintenance or the small size of adult individuals, which allows breeding a high number of animals in the facility.

\subsubsection{Zebrafish and Mammals: Conservation throughout Evolution}

Comparative studies have revealed that the order of neurodevelopmental events across species is highly conserved, even also in zebrafish, although time points, complexity and organization differ, mainly regarding morphogenesis and neurogenesis. In this sense, morphogenesis of zebrafish brain is completed within 3 days and mechanisms behind the formation of different brain structures, such as the neural tube or the telencephalon, differ with respect to those in mammals [187-189]. Nevertheless, the most significant brain regions and major subdivisions, as well as cell types, differentiation, connectivity, signaling pathways and gene expression patterns, are highly conserved [190-192]. Additionally, there are some structural and functionally equivalent neuroanatomic regions such as zebrafish lateral, dorsal and medial pallium, which share characteristics with the human hippocampus, neocortex and amygdala, respectively [193]. While this review will not explain in depth zebrafish and mammals neural structures development and their conservation, we refer the reader to the excellent review by Kozol et al., 2018 [194].

Regarding structural homology and ASD, an interesting example of a critical period is the cerebellar structure and its development. In zebrafish, the cerebellar primordial becomes evident at $22 \mathrm{~h}$ post-fertilization (hpf) [189], and the differentiation of excitatory or inhibitory neurons, glutamatergic and GABAergic respectively, begins at 3 days post-fertilization (dpf) and layers are detectable at $5 \mathrm{dpf}$ [195]. Equivalent to mammals, although in distinct expression domains, the expression by cerebellar progenitors of atoh1 genes gives rise to the excitatory cells and the expression ptf1a leads to the formation of inhibitory cells [196]. Glutamatergic neurons include granule cells and GABAergic neurons include Purkinje cells and in the adult zebrafish such cells are arranged in three layers: molecular, Purkinje cell and granule layer [195]. Purkinje cells are fundamental for the cerebellar neural circuit and its function as they receive synaptic information, process it and relay such information through their efferent projections to the cerebellar nuclei which, in turn, connect 
the cerebellum to the brain and spinal cord, regulating several cognitive, language, motor, sensory and emotional functions [197]. It becomes then evident the importance that these cells have in the proper function of the nervous system and precisely, in the majority of ASD cases, one of the most reproducible and apparent observations is the significant reduction in Purkinje cells number and size [198-200]. Guissart et al., identified several mutations in a nuclear receptor (ROR $\alpha$ ), essential for cerebellar development, in families with variable neurodevelopmental delay and intellectual disability, including cognitive, motor and behavioral phenotypes. They developed a zebrafish mutant model by CRISPR/Cas 9 and were able to recapitulate the neuroanatomical features of patients, showing a reduction of Purkinje and granule cells [201]. This is only an example that provides a rationale for using zebrafish as a model to study neurodevelopmental disorders such as ASD. Nevertheless, the specific role that Purkinje cells have in the development of ASD-like phenotypes is still unclear.

With regard to genetics, the zebrafish genome-sequencing project was initiated at the Welcome Trust Sanger Institute in 2001 and in 2013, Howe et al., released a high-quality sequence assembly of the zebrafish genome, showing that approximately $70 \%$ of the human genes have one zebrafish orthologue, being $>80 \%$ human disease-related genes [202]. Regarding development, as mentioned before, expression patterns in early developmental genes are homologous in both zebrafish and humans and major neurotransmitter systems such as GABA, glutamate, norepinephrine, cholinergic and dopaminergic pathways as well as glial cells are conserved between both species [190,191,203,204]. In addition, Lovett-Barron et al. established a novel method to discover behavioral-related cellular elements and evidenced evolutionarily conserved cellular and molecular systems involved in basic neuromodulatory circuits [205].

In regards to behavior, it has also been demonstrated that zebrafish shares behavioral patterns with humans, including physiological, emotional and social responses [99].

Altogether, these data reaffirm the suitability of the zebrafish as a biomedical research model and its relevance to our understanding of genes, neural circuits and the physiopathology behind neurodevelopmental disorders as ASD.

Henceforth, we will focus on the available genetic strategies applicable in zebrafish in order to develop reliable models to functionally validate ASD-candidate genes, and the techniques that might be utilized to characterize morphological, molecular and behavioral features.

\subsubsection{Gene Targeting in Zebrafish}

One of the main attractions of zebrafish as the disease-model animal is the relative ease and versatility to conduct genetic manipulations in embryos, from transient downregulation or overexpression of a certain gene to permanent gene-targeted mutations [52,206].

Regarding transient reverse genetic approaches, the most commonly used in zebrafish is morpholino-based (MO) expression silencing. MOs are small modified oligonucleotides that are able to bind a selected target by complementary knocking down the gene function without altering the sequence. MOs can either bind the translation start site of the mRNA and thus, interfere with the progression of the ribosomal initiation complex, or to the splicing sites of the pre-mRNAs, leading to abnormal mature mRNAs [207]. Since the release of these antisense oligos in the latest 1990s [208], and given their relatively low cost and ease of use, several zebrafish models have been developed in order to unravel the implication of specific genes in many human diseases. In Table 7, several examples of morpholino-based studies for ASD-candidate genes are shown. Nevertheless, despite its extended use in biomedical research and although the majority of zebrafish studies of neurodevelopmental disorder genes have been based on MOs, these molecules present important disadvantages that should be considered. Firstly, their transient effect (up to $4 \mathrm{dpf}$ ) do not allow to study the gene function beyond the early developmental stages [209]. In addition, it has been reported MOs may lead to off-target effects, resulting in non-specific phenotypes for the gene of study or triggering apoptosis through p53 pathway activation, so a careful design must be carried out, it is recommended to use a control 
MO, rescue experiments with RNA might be performed to confirm MO specificity and when possible, morphant phenotypes should be confirmed in genetic mutants $[210,211]$.

With respect to the generation of stable zebrafish mutant lines, the Targeted Induced Local Lesions in Genomes (TILLING) has been largely used. This technique is based on the exposure to a mutagen known as ethylnitrosourea (ENU), an alkylating agent which, by ethylating oxygen or nitrogen atoms in DNA bases, induces error-prone replication and in turn, leading to random point mutations in the genome. Next, sequencing is performed in order to identify loss of function mutations. From the beginning of its use [212], this procedure has been successfully applied to generate several models of $\mathrm{KO}$ zebrafish. This methodology has been quite useful to correlate specific genes with observed phenotypes, although the generation of a stable mutant line for a gene of interest is relatively limited as it is difficult to identify the desired mutation, costs are substantial and screening zebrafish libraries takes a long time [213]. Some zebrafish ENU knockout models for ASD-candidate genes are listed in Table 7.

In order to solve TILLING drawbacks, nuclease-based technologies were later introduced, speeding up the zebrafish knockout generation and, as previously mentioned, these techniques include TALEN and ZFN, whose functioning is basically the same [214,215]. Despite both techniques enabled researchers to improve the generation of zebrafish mutant lines, it is challenging to specifically design such systems, there is a high ratio of off-target and they are still time and cost consuming. Examples of knockout zebrafish models for ASD-candidate genes are shown in Table 7.

Recently, due to the development and optimization of new genetic editing protocols based on CRISPR/Cas system more accurate mutant zebrafish lines were achieved, as the system offers superior efficiency and flexibility with respect to the previously mentioned gene-editing methods $[52,216,217]$. With regard to CRISPR and neurodevelopmental disorders and in order to highlight its large applicability and utility, it is worth mentioning the extraordinary study recently performed by Thyme et al. They focused on more than 100 genomic loci at which common variants exhibited genome-wide significant associations in a schizophrenia case/control analysis and performed high-throughput CRISPR/Cas9 (132 genes) in zebrafish. By doing so, they were able to observe and describe a phenotypic landscape of schizophrenia-associated genes, to prioritize more than 30 candidates and to provide hypotheses to associate specific genes with biological mechanisms [218]. In Table 7, some examples of CRISPR/Cas9 zebrafish models are listed. 
Table 7. Phenotype observed in Danio rerio ASD-associated genes models. Genes are classified with score 1 (high confidence) or score 2 (strong candidate) following the SFARI Gene database [20,21]. In the cases in which several models have been developed, phenotype refers to the characteristics shared by all of them.

\begin{tabular}{|c|c|c|c|}
\hline ASD-Linked Gene/Danio rerio & Gene Modification Technique & Main Phenotypical Observations & Reference \\
\hline ARID1B/arid1b & Knockdown by MOs & $\begin{array}{l}\text { Reduced body length } \\
\text { Altered expression of chondrogenic/osteogenic genes }\end{array}$ & [219] \\
\hline ARX/arxa & Knockdown by MOs & $\begin{array}{l}\text { Altered brain development } \\
\text { Neuronal alterations }\end{array}$ & [220] \\
\hline AUTS2/auts $2 a$ and auts $2 b$ & Knockdown by MOs & $\begin{array}{c}\text { Microcephaly } \\
\text { Altered jaw development Motor alterations } \\
\text { Neuronal alterations }\end{array}$ & [221] \\
\hline CACNA1C/cacna1c & Knockdown by MOs & $\begin{array}{c}\text { Cardiac alterations } \\
\text { Altered jaw development }\end{array}$ & [222] \\
\hline CEP41/сер41 & Knockdown by MOs & $\begin{array}{l}\text { Neuronal alterations } \\
\text { Social behavior alterations }\end{array}$ & [223] \\
\hline CHD2/chd2 & Knockdown by MOs & $\begin{array}{l}\text { Altered development } \\
\text { Microcephaly, abnormal body curvature } \\
\text { Swim bladder absence } \\
\text { Motor difficulties }\end{array}$ & [224] \\
\hline CHD8/chd8 & $\begin{array}{c}\text { Knockout by CRISPR/Cas9 and } \\
\text { knockdown by MOs }\end{array}$ & $\begin{array}{c}\text { Macrocephaly } \\
\text { Reduction in post-mitotic enteric neurons }\end{array}$ & {$[225,226]$} \\
\hline CNTNAP2/cntnap $2 a$ and cntap $2 b$ & Knockout by ZFN & $\begin{array}{l}\text { Altered development } \\
\text { Microcephaly } \\
\text { Neuronal alterations } \\
\text { Motor alterations }\end{array}$ & [36] \\
\hline CTNND2/ctnnd $2 b$ & Knockdown by MOs & $\begin{array}{l}\text { Reduced body length } \\
\text { Notochord alterations }\end{array}$ & [227] \\
\hline DYRK1A/dyrk1a & Knockout by TALENs & Altered response to social stimuli & [228] \\
\hline$F M R / f m r 1$ & $\begin{array}{c}\text { Knockout by ENU-mutagenesis and } \\
\text { CRISPR/Cas9 }\end{array}$ & $\begin{array}{c}\text { Altered cephalic development } \\
\text { Hyperactivity } \\
\text { Increased anxiety } \\
\text { Altered social behavior } \\
\text { Learning difficulties }\end{array}$ & [229-231] \\
\hline
\end{tabular}


Table 7. Cont.

\begin{tabular}{|c|c|c|c|}
\hline ASD-Linked Gene/Danio rerio & Gene Modification Technique & Main Phenotypical Observations & Reference \\
\hline KCNJ10/kcnj10 & Knockdown by MOs & $\begin{array}{l}\text { Motor alterations } \\
\text { Altered development }\end{array}$ & [232] \\
\hline$K D M 6 A / k d m 6 a$ & Knockdown by MOs & $\begin{array}{c}\text { Reduced body length } \\
\text { Altered development } \\
\text { Notochord alterations } \\
\text { Neuronal alterations }\end{array}$ & {$[233,234]$} \\
\hline MECP2/mеср 2 & $\begin{array}{l}\text { Knockout by ENU-mutagenesis and } \\
\text { knockdown by MOs }\end{array}$ & $\begin{array}{l}\text { Altered immune response } \\
\text { Neuronal alterations }\end{array}$ & [235-237] \\
\hline MET/met & Knockdown by MOs & $\begin{array}{l}\text { High mortality } \\
\text { Neuronal alterations }\end{array}$ & [238] \\
\hline$M Y T 1 L / m y t l 1 a$ and mytl1b & Knockdown by MOs & Reduced levels of oxytocin & [239] \\
\hline NBEA/nbea & $\begin{array}{l}\text { Knockout by ENU-mutagenesis and } \\
\text { TALENs }\end{array}$ & $\begin{array}{l}\text { Neuronal alterations } \\
\text { Altered response to startle stimuli }\end{array}$ & [240] \\
\hline$N R 3 C 2 / n r 3 c 2$ & Knockout by CRISPR/Cas9 & $\begin{array}{l}\text { Altered social behavior } \\
\text { Altered sleep routines }\end{array}$ & [241] \\
\hline OXTR/oxtr & Knockout by TALENs & $\begin{array}{l}\text { Altered oxytocin signaling pathway } \\
\text { Memory alterations in social and non-social recognition }\end{array}$ & [242] \\
\hline RELN/reln & Knockout by TALENs & $\begin{array}{l}\text { Altered social behavior } \\
\text { Altered serotonin signaling pathway }\end{array}$ & [243] \\
\hline RERE/rerea and rereb & Knockout by ENU-mutagenesis & $\begin{array}{l}\text { Altered startle response to stimuli } \\
\text { Vision and hearing difficulties }\end{array}$ & {$[244]$} \\
\hline SHANK3/shank3a and shankb & Knockout by CRISPR/Cas9 & $\begin{array}{c}\text { Altered development } \\
\text { Neuronal alterations } \\
\text { Reduced social behavior, hypoactivity }\end{array}$ & {$[245,246]$} \\
\hline SYNGAP1/syngap $1 a$ and syngap $1 b$ & Knockdown by MOs & $\begin{array}{l}\text { Delayed development } \\
\text { High mortality } \\
\text { Neuronal alterations } \\
\text { Motor difficulties }\end{array}$ & [245] \\
\hline
\end{tabular}


Aside from these genome-editing techniques, several transgenic zebrafish lines fluorescently labeled have been developed throughout the last years, enabling researchers to better characterize neurodevelopmental zebrafish models. Table 8 summarizes some of the available transgenic lines and their specific expression pattern.

Table 8. Examples of developed zebrafish transgenic lines.

\begin{tabular}{ccc}
\hline Transgenic Line & Expression Pattern & Reference \\
\hline ath5:GFP & Retinal ganglion cells & {$[247]$} \\
brn3c:GFP & Retinal ganglion cells & {$[248]$} \\
dat:EGFP & Dopaminergic neurons & {$[249]$} \\
elav13:lynTagRFP & Post-mitotic neurons & {$[250]$} \\
En-1:GFP & Circumferential ascending interneurons & {$[251]$} \\
flk1:GFP & Endothelial cells & {$[252]$} \\
gad1b:RFP & Gabaergic neurons & {$[253]$} \\
gfap:GFP & Radial glial cells & {$[254]$} \\
glyt2:GFP & Glycinergic neurons & {$[255]$} \\
gsx1:GFP & Gabaergic neurons & {$[253]$} \\
isl1:GFP & Cranial motor neurons & {$[256]$} \\
kctd15a:GFP & Torus lateralis & {$[257]$} \\
mnx1:GFP & Motor neurons & {$[258]$} \\
neurod:EGFP & Immature neurons & {$[259]$} \\
neurog1:GFP & Primary neurons & {$[260]$} \\
olig2:EGFP & Oligodendrocytes & {$[261]$} \\
pet1:GFP & Serotonergic neurons & {$[262]$} \\
qrfp:GFP & Rostral hipothalamus & {$[263]$} \\
sox10:GFP & Cone photoreceptor cells & {$[264]$} \\
tbx2b:EGFP & Glutamatergic neurons & {$[265]$} \\
Vglut2a:GFP & Monoaminergic neurons & {$[253]$} \\
vmat2:GFP & & {$[266]$} \\
\hline & crest cells/Neurocranium cartilague & \\
\hline & Coural & \\
\hline
\end{tabular}

\subsubsection{Characterization of Zebrafish Models}

Once the zebrafish knockdown or knockout model to study ASD-candidate genes is generated (with or without transgenic lines), there are several techniques that might be utilized to its accurate characterization, being mainly focused on morphological, molecular and behavioral features.

Regarding morphological characterization, the parameters to be analyzed may include a series of general observations such as body, heart, head, eyes otolith or jaw malformations, yolk deformation or edema and tail bending. Secondly, in order to determine if there exists a delay or abnormality in development some measures might be taken, such as body length, head, eye and yolk sac area or otolith-eye and jaw-eye distance, as well as the different brain regions thickness, area and weight $[246,267,268]$. This characterization is image-based and might be performed manually, or with available commercial image software.

To molecularly characterize zebrafish knockdown or knockdown embryos, researchers can draw upon several techniques, but some of the most commonly applied when it comes to functionally validate candidate genes in the zebrafish model are summarized below.

With regard to gene expression patterns, many of the genes mentioned in transgenic lines in Table 8 can serve as markers in qPCR assays, which offer information about how much the gene is expressed, or in in situ hybridization (ISH) assays with RNA probes, which allow localizing where the gene is being expressed in a precise time point. Other markers to perform ISH or qPCR with, that may be useful in neurodevelopment research are sox2 (neural stem cells self-renewal and pluripotency cells), vglut2.2 (glutamatergic marker), th1 (dopaminergic marker), neurog1 (neuronal determination marker), $c$-fos (neuronal activator marker), $c r h$ (paraventricular nucleus neurons), c-myc (tectal proliferation zone and retina), emx 1 (telencephalon) or ot $x 2 a$ and pax $2 a$ (diencephalon and midbrain-hindbrain boundary) $[267,269,270]$. In addition, immunofluorescence leads the researchers to know where the 
protein is acting, and if there are differences in the amount of protein among individuals, although these assays are relatively limited in zebrafish due to the absence of several specific antibodies. Nevertheless, some have been successfully used such as anti-serotonin (serotonergic neurons), anti-GFAP (radial glia cells) [267], acetylated anti- $\alpha$-tubulin (brain axonal tracts), anti-sox10 (neural crest cells migration) [223], anti-homer1 (post-synaptic protein), anti- synaptophysin (pre-synaptic terminals) [246], znp-1 (primary motor neurons) [269], anti-phosphohistone H3 (M-phase, cell proliferation) [36,226], anti-PCNA (cell proliferation) [270], anti-caspase3 (apoptotic cells) [228] or anti-PSD95 (synaptic marker) [271].

Transcriptomic analyses may be performed in-depth with RNA-sequencing (RNA-seq), although it requires a great amount and high-quality material. Excellent research with RNA-seq, which in addition highlights the suitability of zebrafish to study the implication of environmental factors in ASD-risk, was performed by Lee et al. They exposed embryos to valproic acid-known to induce autism-like effects-and further performed RNA-seq, finding a direct correlation between zebrafish transcriptome and several ASD-associated genes [272]. This technique may also be useful to assess genetic compensation among individuals with phenotypic variability [273].

Concerning behavioral characterization, the precocious behaviors that embryo and larvae display [274] have led to the development of many tests that have proven to be valuable and accurate in zebrafish models. In this sense, different research groups have already study alterations in learning abilities [275], decision-making [276], sensorial capabilities [277,278], emotional responses [279,280] and social interactions $[107,281,282]$, among others. These mechanisms are especially relevant when using zebrafish as a model for studying ASD, as many of these responses are altered in humans suffering from these disorders.

Finally, due to the possibility to use large numbers of the individual to test different drugs or chemicals and the ease of the delivery of the substance—diluted in water [283]—zebrafish has been proposed to conduct high-throughput screenings of neuroactive compounds. This approach would enable the identification of novel compounds with the potential to be used in new treatments for ASD and other NDDs, and additionally, allow the evaluation of their toxicity [284,285].

\subsubsection{Limitations of Zebrafish to Model Human Disorders}

As stated throughout this section, not only can zebrafish be used to study the genetic bases of ASD, but also to highlight the relevance of environmental factors on autism-like phenotypes development [285]. Nevertheless, there are some drawbacks that should be considered when using zebrafish to study human diseases, mainly related to the retention of many duplicate genes due to the whole genome duplication [286]. This means that in some cases, researchers ought to study both genes at the same time. However, this issue might be overcome if the planning of projects is accurately carried out.

\section{Future Challenges}

The present review has been focused on the need of developing reliable models to study the complex genetic background of ASD. These models could be useful to improve our knowledge of the disorder and also to lead the way to the discovery of new potential treatments for patients.

In a disorder as complex as ASD, with individuals having such a diverse genetic background, the possibility of creating personalized models could be very useful in the clinic. Due to the accessibility of the genome editing technologies, such as CRISPR/Cas, it is now more feasible to consider the possibility of creating models that recapitulate the causal mutations detected on patients, and in turn determine which drug therapy is more adequate for each case, which represents one of the first steps towards personalized medicine.

Another interesting approach that has recently been postulated is the possibility of conducting direct reprogramming in vivo [287]. Basically, this technology could allow differentiating adult somatic cells into other cell types without the need for a hiPSC intermediate state. This methodology could be very interesting as a cell therapy option for many diseases and disorders. An imbalance of excitatory 
and inhibitory neuronal networks has been correlated with the presence of ASD and other psychiatric disorders, which potentially could be corrected with this technology. However, more data need to be reconnected to confirm that this correlation is indeed causal and that cell therapy could be an adequate therapy option.

\subsection{In Vitro Modelling}

Despite the potential of NDDs modeling using hiPSC-derived cell lines, there are still some issues that need to be addressed. First, it is important to further optimize reprogramming strategies, as the heterogeneity between hiPSCs colonies is still high. By doing this, it is expected to reduce the variation between cell lines and increase the reproducibility of the experiments. CRISPR/Cas technology could help to address this issue, as it makes it possible to create isogenic cell lines that genetically differ only in the edited position [57]. However, CRISPR/Cas technology has not proven to be highly efficient on hiPSCs, probably due to the protective effect of p53 pathway. This pathway triggers apoptosis when DNA damage is detected, including the DSBs caused by Cas9 [288,289]. Increasing the efficiency of edition and reducing possible off-target effects are other two important milestones to overcome in the future.

Together with deoptimization of the reprogramming and editing mechanisms to reduce technical variability, it would be also necessary to focus on differentiation, standardizing culture conditions to obtain cell lines with reduced variability among each other. Such reduction becomes an especially relevant issue when complex disorders or diseases are being studied, as multiple factors contribute to the global phenotype.

In order to guarantee patients' health and security and unless these issues are properly addressed, researchers may avoid the use of hiPSC-derived cell lines in cell therapy. Additionally, the cost of this type of therapy would still be, nowadays, extremely limiting for its global application.

\subsection{In Vivo Modelling}

New animal mutant lines could be used to study the phenotypic alterations caused by genes associated with ASD, including behavioral, neuroanatomical and morphological features. In this sense, not only can they be useful to address the etiology of the disorder, but also to conduct drug-screening assays in order to identify compounds with the ability to rescue such altered phenotype and thus, offering a promising sign that they could also be effective in human clinical trials [95,99]. In this regard, zebrafish has been postulated as a promising model and, although it is undeniable that zebrafish assays are not enough to translate a compound to clinical trials, it may allow the development of relatively fast and cost-effective drug-screenings, accelerating the pre-screening selection of compounds which in turn, might be further tested in other animal models, such as rodents.

Most models developed to study ASD were designed to study monogenic disorders, which represent a small fraction of ASD cases, so the establishment of new models to study more complex ASD backgrounds is one of the challenges that need to be overcome in the future decades [7].

In addition to this, there are other challenges that need to be addressed. First, behavioral assays need to be improved to better characterize the animal model phenotype and its equivalence with human alterations. The second issue is the lack of genetic diversity in most part of the developed models, as they come from a lineage of inbred animals. For sure, this is a complication for assessing the variability and complexity of a disorder, as well as for testing new potential drug targets to alleviate its symptoms [7].

Animal research has been a source of many debates in the past decade, as there is public concern about the ethics of the use of animal models in science [290,291]. Critics argue that the biological differences between humans and other animals can mislead research investigations (approximately $90 \%$ of drugs that pass animal tests do not pass clinical trials) and that they could be substitute by in vitro models [292]. Although it is true that non-animal models have proven to be very useful for certain assays, to date there is no in vitro model that can fully show the complexity of functioning of a 
living creature [293]. Taking this complexity into account is essential to have a better understanding of biological processes and also to identify the side effects of potential drug treatments. For this reason, many health organizations worldwide still require animal testing before allowing new compounds to go into clinical trials.

However, this does not mean that the use of animals in research should be free of regulation and animal facilities should follow standard procedures to ensure the well-being of the animals. This is necessary from both the ethical and the scientific point of view as trustworthy results can only be obtained if animals are maintained in accurate, non-stressful conditions [290,291,294].

In order to improve the way animals are used in research, many organizations have published guidelines and recommendations to help designing experiments that minimize the use of animals without compromising the acquisition of quality data. Examples include the 3Rs of animal research principle (Reduce, Replace and Refine), as well as more detailed guidelines such as ARRIVE (Animals in Research: Reporting In Vivo Experiments) or PREPARE (Planning Research and Experimental Procedures on Animals: Recommendations for Excellence), which every scientist should take into account for their experiments [295,296].

Author Contributions: S.V.-R., and A.P.-L., wrote the manuscript. S.V.-R. designed and made the figures and Tables 1-4, and Table 6. A.P.-L. designed and made Tables 5, 7 and 8. S.V.-R., A.P.-L., Á.C., C.A., and L.S. conceptualized the manuscript. All authors have read and agreed to the published version of the manuscript.

Funding: Consellería de Educación, Universidade e Formación Profesional (ED431C 2018/28)//FIS PI19/00809 ISCIII//Xunta de Galicia (Centro singular de investigación de Galicia acreditación 2019-2022) and the European Union (European Regional Development Fund - ERDF) (ED431G 2019/02).

Acknowledgments: The support of Fundación Maria José Jove is acknowledged with appreciation.

Conflicts of Interest: The authors declare no conflict of interest and nothing to disclose.

Abbreviations
ABA
ADNP/Adnp
AFF2
ARHGEF9
ARID1B/Arid1b/arid1b
ARRIVE
ARX/arxa
ASD
ASH1L/Ash1l
ASTN2
atoh1
ath5
ATRX
AUTS2/auts2a and auts2b
BCKDK/Bckdk
brn3c
CACNA1C/Cacna1c/cacna1c
Cas
Cas13
Cas9
CDKL5
CEP41/cep41
CHD2/Chd2/chd2
CHD8/Chd8/chd8
CIC/Cic
c-Myc
CNTN5

\section{Abbreviations}

ARHGEF9

ARID1B/Arid1b/arid1b

ARRIVE

ARX/arxa

ASD

ASH1L/Ash1l

ath 5

AUTS2/auts2 $a$ and auts $2 b$

$B C K D K / B c k d k$

brn3c

CACNA1C/Cacna1c/cacna1c

Cas

Cas9

CDKL5

CEP41/cep41

CHD2/Chd2/chd2

CHD8/Chd8/chd8

c-Myc

CNTN5
Applied Behavior Analysis

Activity dependent neuroprotector homeobox

AF4/FMR2 family, member 2

Cdc42 guanine nucleotide exchange factor 9

AT-rich interaction domain 1B

Animals in Research: Reporting In Vivo Experiments

Aristaless related homeobox

Autism Spectrum Disorders

ASH1 like histone lysine methyltransferase

Astrotactin 2

Atonal bHLH transcription factor 1

Atonal bHLH transcription factor 7

$\alpha$ thalassemia/mental retardation syndrome $X$-linked

Autism susceptibility candidate 2

Branched chain ketoacid dehydrogenase kinase

POU class 4 homeobox 3

Calcium channel voltage-dependent, L type, $\alpha 1 \mathrm{C}$ subunit

CRISPR-associated genes

CRISPR-associated endoribonuclease Cas13

CRISPR associated endonuclease Cas9

Cyclin-dependent kinase-like 5

Testis specific, 14

Chromodomain helicase DNA binding protein 2

Chromodomain helicase DNA binding protein 8

Capicua transcriptional repressor

MYC proto-oncogene

Contactin 5 


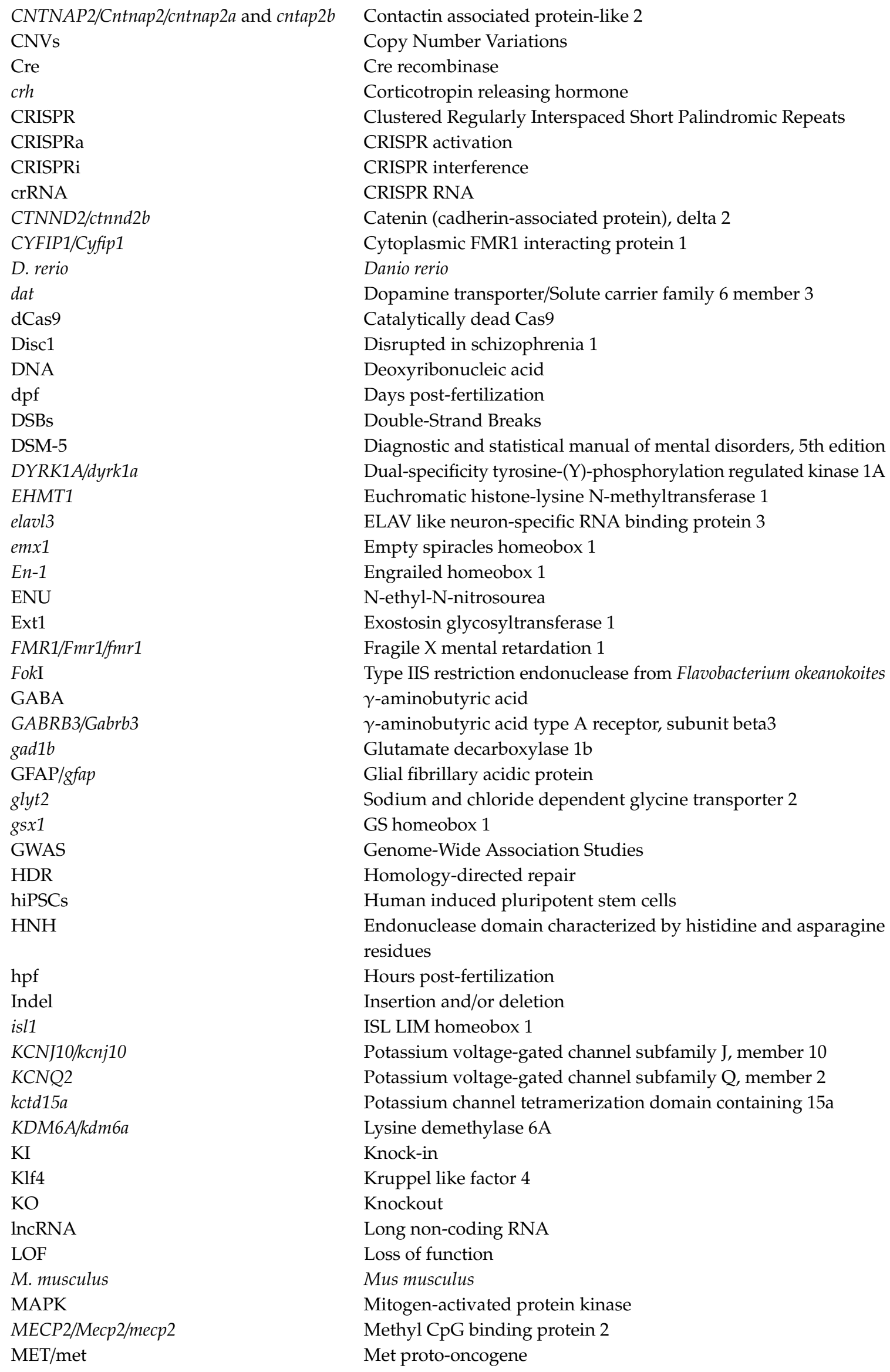




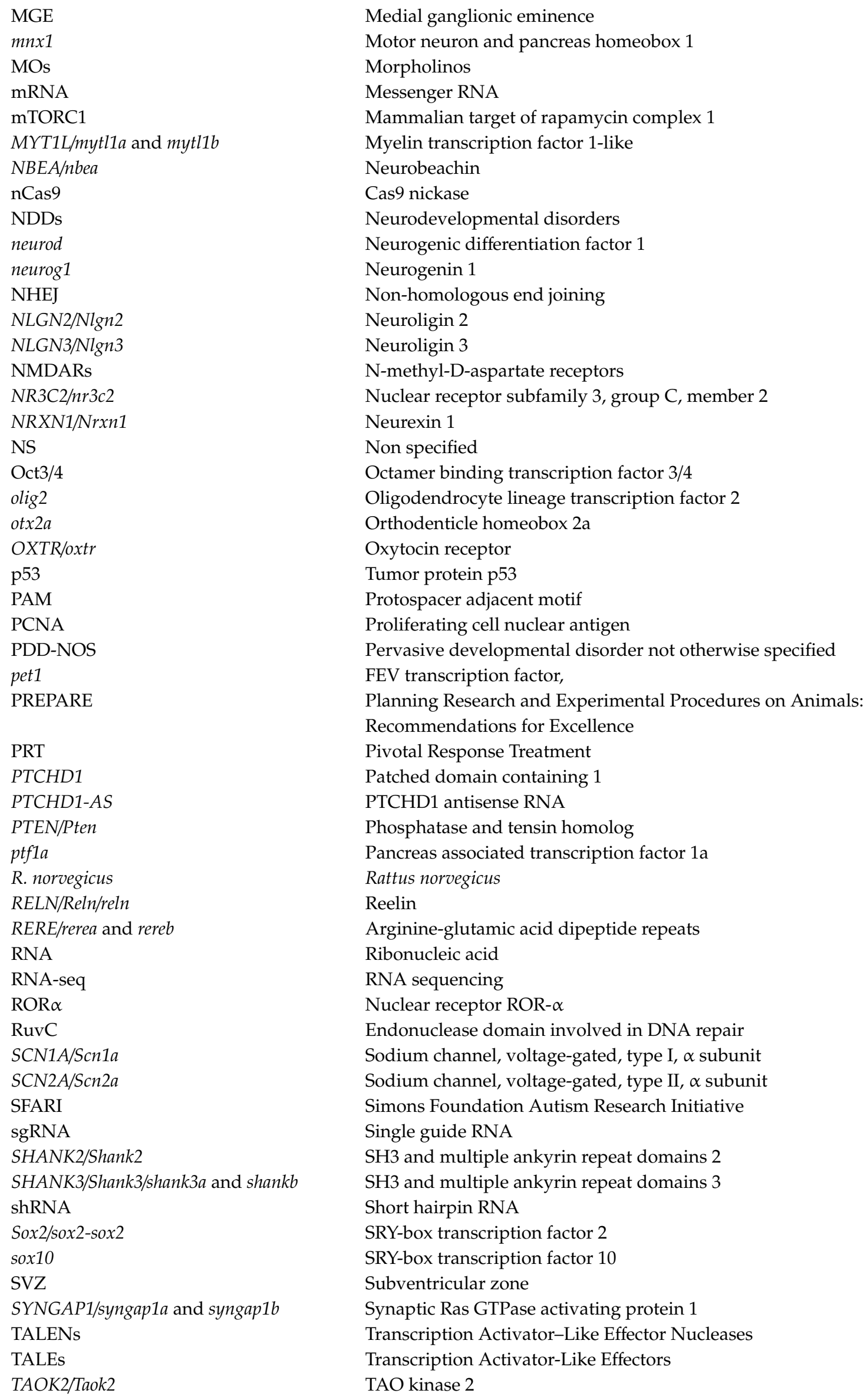




$\begin{array}{ll}\text { TBR1/Tbr1 } & \text { T-box brain transcription factor } 1 \\ \text { tbx } 2 b & \text { T-box transcription factor } 2 \mathrm{~b} \\ \text { TCF4/Tcf4 } & \text { Transcription factor } 4 \\ \text { th1 } & \text { Tyrosine hydroxylase } 1 \\ \text { TILLING } & \text { Targeting Induced Local Lesions in Genomes } \\ \text { tracrRNA } & \text { Trans-activating crRNA } \\ \text { tRNA } & \text { Transfer ribonucleic acid } \\ \text { TRPC6 } & \text { Transient receptor potential cation channel, subfamily C, member } \\ & 6 \\ \text { TSC2/Tsc2 } & \text { Tuberous sclerosis } 2 \\ \text { UBE3A/Ube3a } & \text { Ubiquitin protein ligase E3A } \\ \text { UPF3B/Upf3b } & \text { UPF3B regulator of nonsense mediated mRNA decay } \\ \text { USVs } & \text { Ultrasonic vocalizations } \\ \text { vglut } 2.2 & \text { Vesicular glutamate transporter } 2.2 \\ \text { vglut } 2 a & \text { Vesicular glutamate transporter } 2.1 \\ \text { vmat2 } & \text { Vesicular monoamine transporter } 2 \\ \text { WES } & \text { Whole exome sequencing } \\ \text { WGS } & \text { Whole genome sequencing } \\ \text { ZFNs } & \text { Zinc Finger Nucleases } \\ \text { ZNF804A } & \text { Zinc finger protein 804A }\end{array}$

\section{References}

1. American Psychiatric Association. Diagnostic and Statistical Manual of Mental Disorders (DSM-5), 5th ed.; American Psychiatric Publishing: Washington, DC, USA, 2013.

2. IHME, Global Burden of Disease. Prevalence of Autistic Spectrum Disorder. 2017. Available online: https://ourworldindata.org/grapher/prevalence-of-autistic-spectrum (accessed on 20 March 2020).

3. Lyall, K.; Croen, L.; Daniels, J.; Fallin, M.D.; Ladd-Acosta, C.; Lee, B.K.; Park, B.Y.; Snyder, N.W.; Schendel, D.; Volk, H.; et al. The changing epidemiology of Autism Spectrum Disorders. Annu. Rev. Public Health 2017, 38, 81-102. [CrossRef]

4. Global Burden of Disease Collaborative Network. Global Burden of Disease Study 2016 (GBD 2016) Results. Available online: http://ghdx.healthdata.org/gbd-results-tool (accessed on 20 March 2020).

5. Christensen, D.L.; Baio, J.; Van Naarden Braun, K.; Bilder, D.; Charles, J.; Constantino, J.N.; Daniels, J.; Durkin, M.S.; Fitzgerald, R.T.; Kurzius-Spencer, M.; et al. Prevalence and characteristics of Autism Spectrum Disorder among children aged 8 years-Autism and developmental disabilities monitoring network, 11 sites, United States, 2012. MMWR Surveill. Summ. 2018, 65,1-23. [CrossRef]

6. R Core Team. R: A Language and Environment for Statistical Computing; R Foundation for Statistical Computing: Vienna, Austria, 2020.

7. Mitchell, K.J. (Ed.) The Genetics of Neurodevelopmental Disorders, 1st ed.; John Wiley \& Sons, Inc.: Hoboken, NJ, USA, 2015.

8. Ornoy, A.; Weinstein-Fudim, L.; Ergaz, Z. Prenatal factors associated with Autism Spectrum Disorder (ASD). Reprod. Toxicol. 2015, 56, 155-169. [CrossRef]

9. Kinney, D.K.; Barch, D.H.; Chayka, B.; Napoleon, S.; Munir, K.M. Environmental risk factors for autism: Do they help cause de novo genetic mutations that contribute to the disorder? Med. Hypotheses 2010, 74, 102-106. [CrossRef]

10. Modabbernia, A.; Velthorst, E.; Reichenberg, A. Environmental risk factors for autism: An evidence-based review of systematic reviews and meta-analyses. Mol. Autism 2017, 8, 13. [CrossRef]

11. Folstein, S.E.; Rosen-Sheidley, B. Genetics of austim: Complex aetiology for a heterogeneous disorder. Nat. Rev. Genet. 2001, 2, 943-955. [CrossRef] [PubMed]

12. Rosenberg, R.E.; Law, J.K.; Yenokyan, G.; McGready, J.; Kaufmann, W.E.; Law, P.A. Characteristics and concordance of Autism Spectrum Disorders among 277 twin pairs. Arch. Pediatr. Adolesc. Med. 2009, 163, 907-914. [CrossRef] [PubMed]

13. Geschwind, D.H. Genetics of autism spectrum disorders. Trends Cogn. Sci. 2011, 15, 409-416. [CrossRef] [PubMed] 
14. Canitano, R.; Bozzi, Y. Editorial: Autism spectrum disorders: Developmental trajectories, neurobiological basis, treatment update. Front Psychiatry 2017, 8, 125. [CrossRef] [PubMed]

15. Giovedí, S.; Corradi, A.; Fassio, A.; Benfenati, F. Involvement of synaptic genes in the pathogenesis of Autism Spectrum Disorders: The case of synapsins. Front. Pediatr. 2014, 2, 94. [CrossRef]

16. Iossifov, I.; O’Roak, B.J.; Sanders, S.J.; Ronemus, M.; Krumm, N.; Levy, D.; Stessman, H.A.; Witherspoon, K.T.; Vives, L.; Patterson, K.E.; et al. The contribution of de novo coding mutations to Autism Spectrum Disorder. Nature 2014, 515, 216-221. [CrossRef] [PubMed]

17. Velmeshev, D.; Schirmer, L.; Jung, D.; Haeussler, M.; Perez, Y.; Mayer, S.; Bhaduri, A.; Goyal, N.; Rowitch, D.H.; Kriegstein, A.R. Single-cell genomics identifies cell type-specific molecular changes in autism. Science 2019, 364, 685-689. [CrossRef] [PubMed]

18. Woodbury-Smith, M.; Scherer, S.W. Progress in the genetics of Autism Spectrum Disorder. Dev. Med. Child. Neurol. 2018, 60, 445-451. [CrossRef] [PubMed]

19. Alonso-Gonzalez, A.; Rodriguez-Fontenla, C.; Carracedo, A. De novo mutations (DNMs) in autism spectrum disorder (ASD): Pathway and network analysis. Front. Genet. 2018, 9, 406. [CrossRef] [PubMed]

20. Abrahams, B.S.; Arking, D.E.; Campbell, D.B.; Mefford, H.C.; Morrow, E.M.; Weiss, L.A.; Menashe, I.; Wadkins, T.; Banerjee-Basu, S.; Packer, A. SFARI Gene 2.0: A community-driven knowledgebase for the autism spectrum disorders (ASDs). Mol. Autism 2013, 4, 36. [CrossRef] [PubMed]

21. SFARI Gene. Available online: https://gene.sfari.org/ (accessed on 16 May 2019).

22. Loomes, R.; Hull, L.; Mandy, W.P.L. What is the male-to-female ratio in Autism Spectrum Disorder? A systematic review and meta-analysis. J. Am. Acad. Child Adolesc. Psychiatry 2017, 56, 466-474. [CrossRef]

23. Mullin, A.P.; Gokhale, A.; Moreno-De-Luca, A.; Sanyal, S.; Waddington, J.L.; Faundez, V. Neurodevelopmental disorders: Mechanisms and boundary definitions from genomes, interactomes and proteomes. Transl. Psychiatry 2013, 3, e329. [CrossRef]

24. DeFilippis, M.; Wagner, K.D. Treatment of Autism Spectrum Disorder in children and adolescents. Psychopharmacol. Bull. 2016, 46, 18-41.

25. Farmer, C.; Thurm, A.; Grant, P. Pharmacotherapy for the core symptoms in autistic disorder: Current status of the research. Drugs 2013, 73, 303-314. [CrossRef]

26. Kim, Y.G.; Cha, J.; Chandrasegaran, S. Hybrid restriction enzymes: Zinc finger fusions to Fok I cleavage domain. Proc. Natl. Acad. Sci. USA 1996, 93, 1156-1160. [CrossRef]

27. Christian, M.; Cermak, T.; Doyle, E.L.; Schmidt, C.; Zhang, F.; Hummel, A.; Bogdanove, A.J.; Voytas, D.F. Targeting DNA double-strand breaks with TAL effector nucleases. Genetics 2010, 186, 757-761. [CrossRef] [PubMed]

28. Jinek, M.; East, A.; Cheng, A.; Lin, S.; Ma, E.; Doudna, J. RNA-programmed genome editing in human cells. Elife 2013, 2, e00471. [CrossRef] [PubMed]

29. Doudna, J.A.; Charpentier, E. Genome Editing. The new frontier of genome engineering with CRISPR-Cas9. Science 2014, 346, 1258096. [CrossRef]

30. Hsu, P.D.; Lander, E.S.; Zhang, F. Development and applications of CRISPR-Cas9 for genome engineering. Cell 2014, 157, 1262-1278. [CrossRef]

31. Mojica, F.J.M.; Montoliu, L. On the origin of CRISPR-Cas technology: From prokaryotes to mammals. Trends Microbiol. 2016, 24, 811-820. [CrossRef] [PubMed]

32. Huertas, P. DNA resection in eukaryotes: Deciding how to fix the break. Nat. Struct. Mol. Biol. 2010, 17, 11-16. [CrossRef] [PubMed]

33. Carroll, D. Genome engineering with zinc-finger nucleases. Genetics 2011, 188, 773-782. [CrossRef]

34. Carbery, I.D.; Ji, D.; Harrington, A.; Brown, V.; Weinstein, E.J.; Liaw, L.; Cui, X. Targeted genome modification in mice using zinc-finger nucleases. Genetics 2010, 186, 451-459. [CrossRef]

35. Hockemeyer, D.; Soldner, F.; Beard, C.; Gao, Q.; Mitalipova, M.; DeKelver, R.C.; Katibah, G.E.; Amora, R.; Boydston, E.A.; Zeitler, B.; et al. Efficient targeting of expressed and silent genes in human ESCs and iPSCs using zinc-finger nucleases. Nat. Biotechnol. 2009, 27, 851-857. [CrossRef]

36. Hoffman, E.J.; Turner, K.J.; Fernandez, J.M.; Cifuentes, D.; Ghosh, M.; Ijaz, S.; Jain, R.A.; Kubo, F.; Bill, B.R.; Baier, H.; et al. Estrogens suppress a behavioral phenotype in zebrafish mutants of the autism risk gene, CNTNAP2. Neuron 2016, 89, 725-733. [CrossRef]

37. Amacher, S.L. Emerging gene knockout technology in zebrafish: Zinc-finger nucleases. Br. Funct Genom. Proteom. 2008, 7, 460-464. [CrossRef] 
38. Joung, J.K.; Sander, J.D. TALENs: A widely applicable technology for targeted genome editing. Nat. Rev. Mol. Cell Biol. 2013, 14, 49-55. [CrossRef] [PubMed]

39. Wright, A.V.; Nuñez, J.K.; Doudna, J.A. Biology and applications of CRISPR systems: Harnessing nature's toolbox for genome engineering. Cell 2016, 164, 29-44. [CrossRef] [PubMed]

40. Abudayyeh, O.O.; Gootenberg, J.S.; Essletzbichler, P.; Han, S.; Joung, J.; Belanto, J.J.; Verdine, V.; Cox, D.B.T.; Kellner, M.J.; Regev, A.; et al. RNA targeting with CRISPR-Cas13. Nature 2017, 550, 280-284. [CrossRef]

41. Konermann, S.; Lotfy, P.; Brideau, N.J.; Oki, J.; Shokhirev, M.N.; Hsu, P.D. Transcriptome engineering with RNA-Targeting Type VI-D CRISPR effectors. Cell 2018, 173, 665-676.e14. [CrossRef] [PubMed]

42. Hu, J.H.; Miller, S.M.; Geurts, M.H.; Tang, W.; Chen, L.; Sun, N.; Zeina, C.M.; Gao, X.; Rees, H.A.; Lin, Z.; et al. Evolved Cas9 variants with broad PAM compatibility and high DNA specificity. Nature 2018, 556, 57-63. [CrossRef]

43. Slaymaker, I.M.; Gao, L.; Zetsche, B.; Scott, D.A.; Yan, W.X.; Zhang, F. Rationally engineered Cas9 nucleases with improved specificity. Science 2016, 351, 84-88. [CrossRef]

44. Qi, L.S.; Larson, M.H.; Gilbert, L.A.; Doudna, J.A.; Weissman, J.S.; Arkin, A.P.; Lim, W.A. Repurposing CRISPR as an RNA-guided platform for sequence-specific control of gene expression. Cell 2013, 152, 1173-1183. [CrossRef]

45. Perez-Pinera, P.; Kocak, D.D.; Vockley, C.M.; Adler, A.F.; Kabadi, A.M.; Polstein, L.R.; Thakore, P.I.; Glass, K.A.; Ousterout, D.G.; Leong, K.W.; et al. RNA-guided gene activation by CRISPR-Cas9-based transcription factors. Nat. Methods 2013, 10, 973-976. [CrossRef]

46. Gaudelli, N.M.; Komor, A.C.; Rees, H.A.; Packer, M.S.; Badran, A.H.; Bryson, D.I.; Liu, D.R. Programmable base editing of $A \bullet T$ to $G \bullet C$ in genomic DNA without DNA cleavage. Nature 2017, 551, 464-471. [CrossRef]

47. Anzalone, A.V.; Randolph, P.B.; Davis, J.R.; Sousa, A.A.; Koblan, L.W.; Levy, J.M.; Chen, P.J.; Wilson, C.; Newby, G.A.; Raguram, A.; et al. Search-and-replace genome editing without double-strand breaks or donor DNA. Nature 2019, 576, 149-157. [CrossRef] [PubMed]

48. Smith, C.; Gore, A.; Yan, W.; Abalde-Atristain, L.; Li, Z.; He, C.; Wang, Y.; Brodsky, R.A.; Zhang, K.; Cheng, L.; et al. Whole-Genome Sequencing analysis reveals high specificity of CRISPR/Cas9 and TALEN-based genome editing in human iPSCs. Cell Stem Cell 2014, 15, 12-13. [CrossRef] [PubMed]

49. Cho, S.W.; Kim, S.; Kim, Y.; Kweon, J.; Kim, H.S.; Bae, S.; Kim, J.-S. Analysis of off-target effects of CRISPR/Cas-derived RNA-guided endonucleases and nickases. Genome Res. 2014, 24, 132-141. [CrossRef] [PubMed]

50. Friedland, A.E.; Tzur, Y.B.; Esvelt, K.M.; Colaiácovo, M.P.; Church, G.M.; Calarco, J.A. Heritable genome editing in C. elegans via a CRISPR-Cas9 system. Nat. Methods 2013, 10, 741-743. [CrossRef] [PubMed]

51. Bassett, A.R.; Tibbit, C.; Ponting, C.P.; Liu, J.-L. Highly efficient targeted mutagenesis of Drosophila with the CRISPR/Cas9 System. Cell Rep. 2013, 4, 220-228. [CrossRef] [PubMed]

52. Hwang, W.Y.; Fu, Y.; Reyon, D.; Maeder, M.L.; Tsai, S.Q.; Sander, J.D.; Peterson, R.T.; Yeh, J.-R.J.; Joung, J.K. Efficient genome editing in zebrafish using a CRISPR-Cas system. Nat. Biotechnol. 2013, 31, 227-229. [CrossRef] [PubMed]

53. Li, D.; Qiu, Z.; Shao, Y.; Chen, Y.; Guan, Y.; Liu, M.; Li, Y.; Gao, N.; Wang, L.; Lu, X.; et al. Heritable gene targeting in the mouse and rat using a CRISPR-Cas system. Nat. Biotechnol. 2013, 31, 681-683. [CrossRef]

54. Zhou, Y.; Sharma, J.; Ke, Q.; Landman, R.; Yuan, J.; Chen, H.; Hayden, D.S.; Fisher, J.W.; Jiang, M.; Menegas, W.; et al. Atypical behaviour and connectivity in SHANK3-mutant macaques. Nature 2019, 570, 326-331. [CrossRef]

55. Baltimore, D.; Berg, P.; Botchan, M.; Carroll, D.; Charo, R.A.; Church, G.; Corn, J.E.; Daley, G.Q.; Doudna, J.A.; Fenner, M.; et al. Biotechnology. A prudent path forward for genomic engineering and germline gene modification. Science 2015, 348, 36-38. [CrossRef]

56. Boissart, C.; Poulet, A.; Georges, P.; Darville, H.; Julita, E.; Delorme, R.; Bourgeron, T.; Peschanski, M.; Benchoua, A. Differentiation from human pluripotent stem cells of cortical neurons of the superficial layers amenable to psychiatric disease modeling and high-throughput drug screening. Transl. Psychiatry 2013, 3 , e294. [CrossRef]

57. Shi, Y.; Inoue, H.; Wu, J.C.; Yamanaka, S. Induced pluripotent stem cell technology: A decade of progress. Nat. Rev. Drug Discov. 2017, 16, 115-130. [CrossRef] [PubMed]

58. Takahashi, K.; Yamanaka, S. Induction of pluripotent stem cells from mouse embryonic and adult fibroblast cultures by defined factors. Cell 2006, 126, 663-676. [CrossRef] [PubMed] 
59. Juopperi, T.A.; Song, H.; Ming, G.-L. Modeling neurological diseases using patient-derived induced pluripotent stem cells. Future Neurol. 2011, 6, 363-373. [CrossRef] [PubMed]

60. Brennand, K.J.; Simone, A.; Tran, N.; Gage, F.H. Modeling psychiatric disorders at the cellular and network levels. Mol. Psychiatry 2012, 17, 1239-1253. [CrossRef]

61. Ross, P.J.; Zhang, W.B.; Mok, R.S.F.; Zaslavsky, K.; Deneault, E.; D'Abate, L.; Rodrigues, D.C.; Yuen, R.K.C.; Faheem, M.; Mufteev, M.; et al. Synaptic dysfunction in human neurons with autism-associated deletions in PTCHD1-AS. Biol. Psychiatry 2020, 87, 139-149. [CrossRef]

62. Rontani, P.; Perche, O.; Greetham, L.; Jullien, N.; Gepner, B.; Féron, F.; Nivet, E.; Erard-Garcia, M. Impaired expression of the COSMOC/MOCOS gene unit in ASD patient stem cells. Mol. Psychiatry 2020. [CrossRef]

63. Ross, P.J.; Mok, R.S.F.; Smith, B.S.; Rodrigues, D.C.; Mufteev, M.; Scherer, S.W.; Ellis, J. Modeling neuronal consequences of autism-associated gene regulatory variants with human induced pluripotent stem cells. Mol. Autism 2020, 11, 33. [CrossRef]

64. Nagy, J.; Kobolák, J.; Berzsenyi, S.; Ábrahám, Z.; Avci, H.X.; Bock, I.; Bekes, Z.; Hodoscsek, B.; Chandrasekaran, A.; Téglási, A.; et al. Altered neurite morphology and cholinergic function of induced pluripotent stem cell-derived neurons from a patient with Kleefstra Syndrome and autism. Transl. Psychiatry 2017, 7, e1179. [CrossRef]

65. Nageshappa, S.; Carromeu, C.; Trujillo, C.A.; Mesci, P.; Espuny-Camacho, I.; Pasciuto, E.; Vanderhaeghen, P.; Verfaillie, C.M.; Raitano, S.; Kumar, A.; et al. Altered neuronal network and rescue in a human MECP2 duplication model. Mol. Psychiatry 2016, 21, 178-188. [CrossRef]

66. Avazzadeh, S.; McDonagh, K.; Reilly, J.; Wang, Y.; Boomkamp, S.D.; McInerney, V.; Krawczyk, J.; Fitzgerald, J.; Feerick, N.; O'Sullivan, M.; et al. Increased $\mathrm{Ca}^{2+}$ signaling in NRXN1 $\alpha+/$ - neurons derived from ASD induced pluripotent stem cells. Mol. Autism 2019, 10, 52. [CrossRef]

67. Zaslavsky, K.; Zhang, W.-B.; McCready, F.P.; Rodrigues, D.C.; Deneault, E.; Loo, C.; Zhao, M.; Ross, P.J.; El Hajjar, J.; Romm, A.; et al. SHANK2 mutations associated with autism spectrum disorder cause hyperconnectivity of human neurons. Nat. Neurosci. 2019, 22, 556-564. [CrossRef]

68. Gouder, L.; Vitrac, A.; Goubran-Botros, H.; Danckaert, A.; Tinevez, J.Y.; André-Leroux, G.; Atanasova, E.; Lemière, N.; Biton, A.; Leblond, C.S.; et al. Altered spinogenesis in iPSC-derived cortical neurons from patients with autism carrying de novo SHANK3 mutations. Sci. Rep. 2019, 9, 94. [CrossRef]

69. Darville, H.; Poulet, A.; Rodet-Amsellem, F.; Chatrousse, L.; Pernelle, J.; Boissart, C.; Héron, D.; Nava, C.; Perrier, A.; Jarrige, M.; et al. Human pluripotent stem cell-derived cortical neurons for high throughput medication screening in autism: A proof of concept study in SHANK3 haploinsufficiency syndrome. EBioMedicine 2016, 9, 293-305. [CrossRef] [PubMed]

70. Ebrahimi-Fakhari, D.; Saffari, A.; Wahlster, L.; Di Nardo, A.; Turner, D.; Lewis, T.L.; Conrad, C.; Rothberg, J.M.; Lipton, J.O.; Kölker, S.; et al. Impaired mitochondrial dynamics and mitophagy in neuronal models of tuberous sclerosis complex. Cell Rep. 2016, 17, 1053-1070. [CrossRef] [PubMed]

71. Winden, K.D.; Sundberg, M.; Yang, C.; Wafa, S.M.A.; Dwyer, S.; Chen, P.F.; Buttermore, E.D.; Sahin, M. Biallelic mutations in TSC2 lead to abnormalities associated with cortical tubers in human iPSC-derived neurons. J. Neurosci. 2019, 39, 9294-9305. [CrossRef] [PubMed]

72. Arioka, Y.; Shishido, E.; Kubo, H.; Kushima, I.; Yoshimi, A.; Kimura, H.; Ishizuka, K.; Aleksic, B.; Maeda, T.; Ishikawa, M.; et al. Single-cell trajectory analysis of human homogenous neurons carrying a rare RELN variant. Transl. Psychiatry 2018, 8, 129. [CrossRef]

73. Deneault, E.; White, S.H.; Rodrigues, D.C.; Ross, P.J.; Faheem, M.; Zaslavsky, K.; Wang, Z.; Alexandrova, R.; Pellecchia, G.; Wei, W.; et al. Complete disruption of autism-susceptibility genes by gene editing predominantly reduces functional connectivity of isogenic human neurons. Stem Cell Rep. 2018, 11, 1211-1225. [CrossRef]

74. Deneault, E.; Faheem, M.; White, S.H.; Rodrigues, D.C.; Sun, S.; Wei, W.; Piekna, A.; Thompson, T.; Howe, J.L.; Chalil, L.; et al. CNTN5-/+ or EHMT2-/+ human iPSC-derived neurons from individuals with autism develop hyperactive neuronal networks. Elife 2019, 8, e40092. [CrossRef]

75. Machado, C.O.F.; Griesi-Oliveira, K.; Rosenberg, C.; Kok, F.; Martins, S.; Rita Passos-Bueno, M.; Sertie, A.L. Collybistin binds and inhibits mTORC1 signaling: A potential novel mechanism contributing to intellectual disability and autism. Eur. J. Hum. Genet. 2016, 24, 59-65. [CrossRef] 
76. Paşca, S.P.; Portmann, T.; Voineagu, I.; Yazawa, M.; Shcheglovitov, A.; Paşca, A.M.; Cord, B.; Palmer, T.D.; Chikahisa, S.; Nishino, S.; et al. Using iPSC-derived neurons to uncover cellular phenotypes associated with Timothy Syndrome. Nat. Med. 2011, 17, 1657-1662. [CrossRef]

77. Tian, Y.; Voineagu, I.; Paşca, S.P.; Won, H.; Chandran, V.; Horvath, S.; Dolmetsch, R.E.; Geschwind, D.H. Alteration in basal and depolarization induced transcriptional network in iPSC derived neurons from Timothy Syndrome. Genome Med. 2014, 6, 75. [CrossRef] [PubMed]

78. Gao, Y.; Irvine, E.E.; Eleftheriadou, I.; Naranjo, C.J.; Hearn-Yeates, F.; Bosch, L.; Glegola, J.A.; Murdoch, L.; Czerniak, A.; Meloni, I.; et al. Gene replacement ameliorates deficits in mouse and human models of cyclin-dependent kinase-like 5 disorder. Brain 2020, 143, 811-832. [CrossRef] [PubMed]

79. Wang, P.; Lin, M.; Pedrosa, E.; Hrabovsky, A.; Zhang, Z.; Guo, W.; Lachman, H.M.; Zheng, D. CRISPR/Cas9-mediated heterozygous knockout of the autism gene CHD8 and characterization of its transcriptional networks in neurodevelopment. Mol. Autism 2015, 6, 55. [CrossRef] [PubMed]

80. Boland, M.J.; Nazor, K.L.; Tran, H.T.; Szücs, A.; Lynch, C.L.; Paredes, R.; Tassone, F.; Sanna, P.P.; Hagerman, R.J.; Loring, J.F. Molecular analyses of neurogenic defects in a human pluripotent stem cell model of Fragile $\mathrm{X}$ Syndrome. Brain 2017, 140, 582-598. [CrossRef] [PubMed]

81. Doers, M.E.; Musser, M.T.; Nichol, R.; Berndt, E.R.; Baker, M.; Gomez, T.M.; Zhang, S.C.; Abbeduto, L.; Bhattacharyya, A. iPSC-derived forebrain neurons from FXS individuals show defects in initial neurite outgrowth. Stem Cells Dev. 2014, 23, 1777-1787. [CrossRef] [PubMed]

82. Sheridan, S.D.; Theriault, K.M.; Reis, S.A.; Zhou, F.; Madison, J.M.; Daheron, L.; Loring, J.F.; Haggarty, S.J. Epigenetic characterization of the FMR1 gene and aberrant neurodevelopment in human induced pluripotent stem cell models of Fragile X Syndrome. PLoS ONE 2011, 6, e26203. [CrossRef] [PubMed]

83. Huang, G.; Chen, S.; Chen, X.; Zheng, J.; Xu, Z.; Torshizi, A.D.; Gong, S.; Chen, Q.; Ma, X.; Yu, J.; et al. Uncovering the functional link between SHANK3 deletions and deficiency in neurodevelopment using iPSC-derived human neurons. Front. Neuroanat. 2019, 13, 23. [CrossRef] [PubMed]

84. Shcheglovitov, A.; Shcheglovitova, O.; Yazawa, M.; Portmann, T.; Shu, R.; Sebastiano, V.; Krawisz, A.; Froehlich, W.; Bernstein, J.A.; Hallmayer, J.F.; et al. SHANK3 and IGF1 restore synaptic deficits in neurons from 22q13 deletion syndrome patients. Nature 2013, 503, 267-271. [CrossRef]

85. Griesi-Oliveira, K.; Acab, A.; Gupta, A.R.; Sunaga, D.Y.; Chailangkarn, T.; Nicol, X.; Nunez, Y.; Walker, M.F.; Murdoch, J.D.; Sanders, S.J.; et al. Modeling non-syndromic autism and the impact of TRPC6 disruption in human neurons. Mol. Psychiatry 2015, 20, 1350-1365. [CrossRef]

86. Wang, P.; Mokhtari, R.; Pedrosa, E.; Kirschenbaum, M.; Bayrak, C.; Zheng, D.; Lachman, H.M. CRISPR/Cas9-mediated heterozygous knockout of the autism gene CHD8 and characterization of its transcriptional networks in cerebral organoids derived from iPS cells. Mol. Autism 2017, 8, 11. [CrossRef]

87. Lam, M.; Moslem, M.; Bryois, J.; Pronk, R.J.; Uhlin, E.; Ellström, I.D.; Laan, L.; Olive, J.; Morse, R.; Rönnholm, H.; et al. Single cell analysis of autism patient with bi-allelic NRXN1-alpha deletion reveals skewed fate choice in neural progenitors and impaired neuronal functionality. Exp. Cell Res. 2019, 383, 111469. [CrossRef] [PubMed]

88. Zeng, L.; Zhang, P.; Shi, L.; Yamamoto, V.; Lu, W.; Wang, K. Functional impacts of NRXN1 knockdown on neurodevelopment in stem cell models. PLoS ONE 2013, 8, e59685. [CrossRef] [PubMed]

89. Sánchez-Sánchez, S.M.; Magdalon, J.; Griesi-Oliveira, K.; Yamamoto, G.L.; Santacruz-Perez, C.; Fogo, M.; Passos-Bueno, M.R.; Sertié, A.L. Rare RELN variants affect Reelin-DAB1 signal transduction in Autism Spectrum Disorder. Hum. Mutat. 2018, 39, 1372-1383. [CrossRef] [PubMed]

90. Chen, J.; Lin, M.; Hrabovsky, A.; Pedrosa, E.; Dean, J.; Jain, S.; Zheng, D.; Lachman, H.M. ZNF804A transcriptional networks in differentiating neurons derived from induced pluripotent stem cells of human origin. PLoS ONE 2015, 10, e0124597. [CrossRef] [PubMed]

91. Kathuria, A.; Nowosiad, P.; Jagasia, R.; Aigner, S.; Taylor, R.D.; Andreae, L.C.; Gatford, N.J.F.; Lucchesi, W.; Srivastava, D.P.; Price, J. Stem cell-derived neurons from autistic individuals with SHANK3 mutation show morphogenetic abnormalities during early development. Mol. Psychiatry 2018, 23, 735-746. [CrossRef]

92. Sundberg, M.; Tochitsky, I.; Buchholz, D.E.; Winden, K.; Kujala, V.; Kapur, K.; Cataltepe, D.; Turner, D.; Han, M.J.; Woolf, C.J.; et al. Purkinje cells derived from TSC patients display hypoexcitability and synaptic deficits associated with reduced FMRP levels and reversed by rapamycin. Mol. Psychiatry 2018, 23, 2167-2183. [CrossRef] 
93. Silverman, J.L.; Yang, M.; Lord, C.; Crawley, J.N. Behavioural phenotyping assays for mouse models of autism. Nat. Rev. Neurosci. 2010, 11, 490-502. [CrossRef] [PubMed]

94. Patterson, P.H. Modeling autistic features in animals. Pediatr. Res. 2011, 69, 34R-40R. [CrossRef]

95. Norton, W.H.J. Toward developmental models of psychiatric disorders in zebrafish. Front. Neural Circuits 2013, 7, 79. [CrossRef]

96. Sakai, C.; Ijaz, S.; Hoffman, E.J. Zebrafish models of neurodevelopmental disorders: Past, present, and future. Front. Mol. Neurosci. 2018, 11, 294. [CrossRef]

97. Ellenbroek, B.; Youn, J. Rodent models in neuroscience research: Is it a rat race? Dis. Model. Mech. 2016, 9 , 1079-1087. [CrossRef] [PubMed]

98. Wöhr, M.; Scattoni, M.L. Behavioural methods used in rodent models of Autism Spectrum Disorders: Current standards and new developments. Behav. Brain Res. 2013, 251, 5-17. [CrossRef] [PubMed]

99. Meshalkina, D.A.; Kizlyk, M.N.; Kysil, E.V.; Collier, A.D.; Echevarria, D.J.; Abreu, M.S.; Barcellos, L.J.G.; Song, C.; Warnick, J.E.; Kyzar, E.J.; et al. Zebrafish models of Autism Spectrum Disorder. Exp. Neurol. 2018, 299, 207-216. [CrossRef] [PubMed]

100. Meyza, K.Z.; Defensor, E.B.; Jensen, A.L.; Corley, M.J.; Pearson, B.L.; Pobbe, R.L.H.; Bolivar, V.J.; Blanchard, D.C.; Blanchard, R.J. The BTBR T+tf/J mouse model for Autism Spectrum Disorders-in search of biomarkers. Behav. Brain Res. 2013, 251, 25-34. [CrossRef]

101. Amram, N.; Hacohen-Kleiman, G.; Sragovich, S.; Malishkevich, A.; Katz, J.; Touloumi, O.; Lagoudaki, R.; Grigoriadis, N.C.; Giladi, E.; Yeheskel, A.; et al. Sexual divergence in microtubule function: The novel intranasal microtubule targeting SKIP normalizes axonal transport and enhances memory. Mol. Psychiatry 2016, 21, 1467-1476. [CrossRef]

102. Sragovich, S.; Malishkevich, A.; Piontkewitz, Y.; Giladi, E.; Touloumi, O.; Lagoudaki, R.; Grigoriadis, N.; Gozes, I. The autism/neuroprotection-linked ADNP/NAP regulate the excitatory glutamatergic synapse. Transl. Psychiatry 2019, 9, 2. [CrossRef]

103. Vulih-Shultzman, I.; Pinhasov, A.; Mandel, S.; Grigoriadis, N.; Touloumi, O.; Pittel, Z.; Gozes, I. Activity-dependent neuroprotective protein snippet NAP reduces tau hyperphosphorylation and enhances learning in a novel transgenic mouse model. J. Pharmacol. Exp. Ther. 2007, 323, 438-449. [CrossRef]

104. Celen, C.; Chuang, J.-C.; Luo, X.; Nijem, N.; Walker, A.K.; Chen, F.; Zhang, S.; Chung, A.S.; Nguyen, L.H.; Nassour, I.; et al. Arid1b haploinsufficient mice reveal neuropsychiatric phenotypes and reversible causes of growth impairment. Elife 2017, 6, e25730. [CrossRef]

105. Shibutani, M.; Horii, T.; Shoji, H.; Morita, S.; Kimura, M.; Terawaki, N.; Miyakawa, T.; Hatada, I.; Shibutani, M.; Horii, T.; et al. Arid1b Haploinsufficiency Causes Abnormal Brain Gene Expression and Autism-Related Behaviors in Mice. Int. J. Mol. Sci. 2017, 18, 1872. [CrossRef]

106. Brinkmeier, M.L.; Geister, K.A.; Jones, M.; Waqas, M.; Maillard, I.; Camper, S.A. The histone methyltransferase gene Absent, Small, or Homeotic Discs-1 Like is required for normal hox gene expression and fertility in mice. Biol. Reprod. 2015, 93, 121. [CrossRef]

107. Xia, M.; Liu, J.; Wu, X.; Liu, S.; Li, G.; Han, C.; Song, L.; Li, Z.; Wang, Q.; Wang, J.; et al. Histone Methyltransferase Ash1l Suppresses Interleukin-6 Production and Inflammatory Autoimmune Diseases by Inducing the Ubiquitin-Editing Enzyme A20. Immunity 2013, 39, 470-481. [CrossRef] [PubMed]

108. Zhu, T.; Liang, C.; Li, D.; Tian, M.; Liu, S.; Gao, G.; Guan, J.S. Histone methyltransferase Ash1L mediates activity-dependent repression of neurexin-1 $\alpha$. Sci. Rep. 2016, 6, 26597. [CrossRef] [PubMed]

109. Kim, Y.J.; Khoshkhoo, S.; Frankowski, J.C.; Zhu, B.; Abbasi, S.; Lee, S.; Wu, Y.E.; Hunt, R.F. Chd2 Is Necessary for Neural Circuit Development and Long-Term Memory. Neuron 2018, 100, 1180-1193.e6. [CrossRef] [PubMed]

110. Nagarajan, P.; Onami, T.M.; Rajagopalan, S.; Kania, S.; Donnell, R.; Venkatachalam, S. Role of chromodomain helicase DNA-binding protein 2 in DNA damage response signaling and tumorigenesis. Oncogene 2009, 28, 1053-1062. [CrossRef]

111. Durak, O.; Gao, F.; Kaeser-Woo, Y.J.; Rueda, R.; Martorell, A.J.; Nott, A.; Liu, C.Y.; Watson, L.A.; Tsai, L.-H. Chd8 mediates cortical neurogenesis via transcriptional regulation of cell cycle and Wnt signaling. Nat. Neurosci. 2016, 19, 1477-1488. [CrossRef] [PubMed]

112. Gompers, A.L.; Su-Feher, L.; Ellegood, J.; Copping, N.A.; Riyadh, M.A.; Stradleigh, T.W.; Pride, M.C.; Schaffler, M.D.; Wade, A.A.; Catta-Preta, R.; et al. Germline Chd8 haploinsufficiency alters brain development in mouse. Nat. Neurosci. 2017, 20, 1062-1073. [CrossRef] [PubMed] 
113. Jung, H.; Park, H.; Choi, Y.; Kang, H.; Lee, E.; Kweon, H.; Roh, J.D.; Ellegood, J.; Choi, W.; Kang, J.; et al. Sexually dimorphic behavior, neuronal activity, and gene expression in Chd8-mutant mice. Nat. Neurosci. 2018, 21, 1218-1228. [CrossRef]

114. Katayama, Y.; Nishiyama, M.; Shoji, H.; Ohkawa, Y.; Kawamura, A.; Sato, T.; Suyama, M.; Takumi, T.; Miyakawa, T.; Nakayama, K.I. CHD8 haploinsufficiency results in autistic-like phenotypes in mice. Nature 2016, 537, 675-679. [CrossRef]

115. Nishiyama, M.; Oshikawa, K.; Tsukada, Y.; Nakagawa, T.; Iemura, S.; Natsume, T.; Fan, Y.; Kikuchi, A.; Skoultchi, A.I.; Nakayama, K.I. CHD8 suppresses p53-mediated apoptosis through histone H1 recruitment during early embryogenesis. Nat. Cell Biol. 2009, 11, 172-182. [CrossRef]

116. Platt, R.J.; Zhou, Y.; Slaymaker, I.M.; Shetty, A.S.; Weisbach, N.R.; Kim, J.-A.; Sharma, J.; Desai, M.; Sood, S.; Kempton, H.R.; et al. Chd8 Mutation Leads to Autistic-like Behaviors and Impaired Striatal Circuits. Cell Rep. 2017, 19, 335-350. [CrossRef]

117. Suetterlin, P.; Hurley, S.; Mohan, C.; Riegman, K.L.H.; Pagani, M.; Caruso, A.; Ellegood, J.; Galbusera, A.; Crespo-Enriquez, I.; Michetti, C.; et al. Altered neocortical gene expression, brain overgrowth and functional over-connectivity in chd8 haploinsufficient mice. Cereb. Cortex 2018, 28, 2192-2206. [CrossRef] [PubMed]

118. Zhao, C.; Dong, C.; Frah, M.; Deng, Y.; Marie, C.; Zhang, F.; Xu, L.; Ma, Z.; Dong, X.; Lin, Y.; et al. Dual Requirement of CHD8 for Chromatin Landscape Establishment and Histone Methyltransferase Recruitment to Promote CNS Myelination and Repair. Dev. Cell 2018, 45, 753-768.e8. [CrossRef] [PubMed]

119. Lu, H.-C.; Tan, Q.; Rousseaux, M.W.C.; Wang, W.; Kim, J.-Y.; Richman, R.; Wan, Y.-W.; Yeh, S.-Y.; Patel, J.M.; Liu, X.; et al. Disruption of the ATXN1-CIC complex causes a spectrum of neurobehavioral phenotypes in mice and humans. Nat. Genet. 2017, 49, 527-536. [CrossRef] [PubMed]

120. Horresh, I.; Bar, V.; Kissil, J.L.; Peles, E. Organization of myelinated axons by Caspr and Caspr2 requires the cytoskeletal adapter protein 4.1B. J. Neurosci. 2010, 30, 2480-2489. [CrossRef] [PubMed]

121. Peñagarikano, O.; Abrahams, B.S.; Herman, E.I.; Winden, K.D.; Gdalyahu, A.; Dong, H.; Sonnenblick, L.I.; Gruver, R.; Almajano, J.; Bragin, A.; et al. Absence of CNTNAP2 leads to epilepsy, neuronal migration abnormalities, and core autism-related deficits. Cell 2011, 147, 235-246. [CrossRef]

122. Peñagarikano, O.; Lázaro, M.T.; Lu, X.-H.; Gordon, A.; Dong, H.; Lam, H.A.; Peles, E.; Maidment, N.T.; Murphy, N.P.; Yang, X.W.; et al. Exogenous and evoked oxytocin restores social behavior in the Cntnap2 mouse model of autism. Sci. Transl. Med. 2015, 7, ra8-ra271. [CrossRef]

123. Poliak, S.; Salomon, D.; Elhanany, H.; Sabanay, H.; Kiernan, B.; Pevny, L.; Stewart, C.L.; Xu, X.; Chiu, S.-Y.; Shrager, P.; et al. Juxtaparanodal clustering of Shaker-like $\mathrm{K}^{+}$channels in myelinated axons depends on Caspr2 and TAG-1. J. Cell Biol. 2003, 162, 1149-1160. [CrossRef]

124. Schaafsma, S.M.; Gagnidze, K.; Reyes, A.; Norstedt, N.; Månsson, K.; Francis, K.; Pfaff, D.W. Sex-specific gene-environment interactions underlying ASD-like behaviors. Proc. Natl. Acad. Sci. USA 2017, 114, 1383-1388. [CrossRef]

125. Selimbeyoglu, A.; Kim, C.K.; Inoue, M.; Lee, S.Y.; Hong, A.S.O.; Kauvar, I.; Ramakrishnan, C.; Fenno, L.E.; Davidson, T.J.; Wright, M.; et al. Modulation of prefrontal cortex excitation/inhibition balance rescues social behavior in CNTNAP2 -deficient mice. Sci. Transl. Med. 2017, 9, eaah6733. [CrossRef]

126. DeLorey, T.M.; Handforth, A.; Anagnostaras, S.G.; Homanics, G.E.; Minassian, B.A.; Asatourian, A.; Fanselow, M.S.; Delgado-Escueta, A.; Ellison, G.D.; Olsen, R.W. Mice lacking the $\beta 3$ subunit of the GABA(A) receptor have the epilepsy phenotype and many of the behavioral characteristics of Angelman syndrome. J. Neurosci. 1998, 18, 8505-8514. [CrossRef]

127. DeLorey, T.M.; Sahbaie, P.; Hashemi, E.; Li, W.-W.; Salehi, A.; Clark, D.J. Somatosensory and sensorimotor consequences associated with the heterozygous disruption of the autism candidate gene, Gabrb3. Behav. Brain Res. 2011, 216, 36-45. [CrossRef] [PubMed]

128. Li, S.; Kumar, T.P.; Joshee, S.; Kirschstein, T.; Subburaju, S.; Khalili, J.S.; Kloepper, J.; Du, C.; Elkhal, A.; Szabó, G.; et al. Endothelial cell-derived GABA signaling modulates neuronal migration and postnatal behavior. Cell Res. 2018, 28, 221-248. [CrossRef] [PubMed]

129. Liljelund, P.; Handforth, A.; Homanics, G.E.; Olsen, R.W. GABAA receptor $\beta 3$ subunit gene-deficient heterozygous mice show parent-of-origin and gender-related differences in $\beta 3$ subunit levels, EEG, and behavior. Dev. Brain Res. 2005, 157, 150-161. [CrossRef] [PubMed] 
130. Orefice, L.L.; Zimmerman, A.L.; Chirila, A.M.; Sleboda, S.J.; Head, J.P.; Ginty, D.D. Peripheral Mechanosensory Neuron Dysfunction Underlies Tactile and Behavioral Deficits in Mouse Models of ASDs. Cell 2016, 166, 299-313. [CrossRef]

131. Cabral-Costa, J.V.; Andreotti, D.Z.; Mello, N.P.; Scavone, C.; Camandola, S.; Kawamoto, E.M. Intermittent fasting uncovers and rescues cognitive phenotypes in PTEN neuronal haploinsufficient mice. Sci. Rep. 2018, 8, 8595. [CrossRef]

132. Clipperton-Allen, A.E.; Page, D.T. Decreased aggression and increased repetitive behavior in Pten haploinsufficient mice. Genes Brain Behav. 2015, 14, 145-157. [CrossRef]

133. Cupolillo, D.; Hoxha, E.; Faralli, A.; De Luca, A.; Rossi, F.; Tempia, F.; Carulli, D. Autistic-like traits and cerebellar dysfunction in purkinje cell PTEN knock-out mice. Neuropsychopharmacology 2016, 41, 1457-1466. [CrossRef]

134. Kwon, C.-H.; Luikart, B.W.; Powell, C.M.; Zhou, J.; Matheny, S.A.; Zhang, W.; Li, Y.; Baker, S.J.; Parada, L.F. Pten Regulates Neuronal Arborization and Social Interaction in Mice. Neuron 2006, 50, 377-388. [CrossRef]

135. Vogt, D.; Cho, K.K.A.; Lee, A.T.; Sohal, V.S.; Rubenstein, J.L.R. The Parvalbumin/Somatostatin Ratio Is Increased in Pten Mutant Mice and by Human PTEN ASD Alleles. Cell Rep. 2015, 11, 944-956. [CrossRef]

136. Williams, M.R.; DeSpenza, T.; Li, M.; Gulledge, A.T.; Luikart, B.W. Hyperactivity of Newborn Pten Knock-out Neurons Results from Increased Excitatory Synaptic Drive. J. Neurosci. 2015, 35, 943-959. [CrossRef]

137. Zhou, J.; Blundell, J.; Ogawa, S.; Kwon, C.H.; Zhang, W.; Sinton, C.; Powell, C.M.; Parada, L.F. Pharmacological inhibition of mTORCl suppresses anatomical, cellular, and behavioral abnormalities in neural-specific PTEN knock-out mice. J. Neurosci. 2009, 29, 1773-1783. [CrossRef] [PubMed]

138. Mullen, B.R.; Khialeeva, E.; Hoffman, D.B.; Ghiani, C.A.; Carpenter, E.M. Decreased reelin expression and organophosphate pesticide exposure alters mouse behaviour and brain morphology. ASN Neuro 2013, 5, 27-42. [CrossRef] [PubMed]

139. Nyarenchi, O.M.; Scherer, A.; Wilson, S.; Fulkerson, D.H. Cloacal exstrophy with extensive Chiari II malformation: Case report and review of the literature. Child's Nerv. Syst. 2014, 30, 337-343. [CrossRef] [PubMed]

140. Rice, D.S.; Nusinowitz, S.; Azimi, A.M.; Martínez, A.; Soriano, E.; Curran, T. The Reelin Pathway Modulates the Structure and Function of Retinal Synaptic Circuitry. Neuron 2001, 31, 929-941. [CrossRef]

141. Hawkins, N.A.; Martin, M.S.; Frankel, W.N.; Kearney, J.A.; Escayg, A. Neuronal voltage-gated ion channels are genetic modifiers of generalized epilepsy with febrile seizures plus. Neurobiol. Dis. 2011, 41, 655-660. [CrossRef] [PubMed]

142. Planells-Cases, R.; Caprini, M.; Zhang, J.; Rockenstein, E.M.; Rivera, R.R.; Murre, C.; Masliah, E.; Montal, M. Neuronal death and perinatal lethality in voltage-gated sodium channel $\alpha(\mathrm{II})$-deficient mice. Biophys. J. 2000, 78, 2878-2891. [CrossRef]

143. Tatsukawa, T.; Raveau, M.; Ogiwara, I.; Hattori, S.; Miyamoto, H.; Mazaki, E.; Itohara, S.; Miyakawa, T.; Montal, M.; Yamakawa, K. Scn2a haploinsufficient mice display a spectrum of phenotypes affecting anxiety, sociability, memory flexibility and ampakine CX516 rescues their hyperactivity. Mol. Autism 2019, 10, 15. [CrossRef] [PubMed]

144. Chung, C.; Ha, S.; Kang, H.; Lee, J.; Um, S.M.; Yan, H.; Yoo, Y.-E.; Yoo, T.; Jung, H.; Lee, D.; et al. Early Correction of N-Methyl-D-Aspartate Receptor Function Improves Autistic-like Social Behaviors in Adult Shank2 ${ }^{-/-}$Mice. Biol. Psychiatry 2019, 85, 534-543. [CrossRef]

145. Ha, S.; Lee, D.; Cho, Y.S.; Chung, C.; Yoo, Y.-E.; Kim, J.; Lee, J.; Kim, W.; Kim, H.; Bae, Y.C.; et al. Cerebellar Shank2 Regulates Excitatory Synapse Density, Motor Coordination, and Specific Repetitive and Anxiety-Like Behaviors. J. Neurosci. 2016, 36, 12129-12143. [CrossRef]

146. Lee, E.-J.; Lee, H.; Huang, T.-N.; Chung, C.; Shin, W.; Kim, K.; Koh, J.-Y.; Hsueh, Y.-P.; Kim, E. Trans-synaptic zinc mobilization improves social interaction in two mouse models of autism through NMDAR activation. Nat. Commun. 2015, 6, 7168. [CrossRef]

147. Lim, C.-S.; Kim, H.; Yu, N.-K.; Kang, S.J.; Kim, T.; Ko, H.-G.; Lee, J.; Yang, J.; Ryu, H.-H.; Park, T.; et al. Enhancing inhibitory synaptic function reverses spatial memory deficits in Shank2 mutant mice. Neuropharmacology 2017, 112, 104-112. [CrossRef] [PubMed]

148. Won, H.; Lee, H.-R.; Gee, H.Y.; Mah, W.; Kim, J.-I.; Lee, J.; Ha, S.; Chung, C.; Jung, E.S.; Cho, Y.S.; et al. Autistic-like social behaviour in Shank2-mutant mice improved by restoring NMDA receptor function. Nature 2012, 486, 261-265. [CrossRef] [PubMed] 
149. Richter, M.; Murtaza, N.; Scharrenberg, R.; White, S.H.; Johanns, O.; Walker, S.; Yuen, R.K.C.; Schwanke, B.; Bedürftig, B.; Henis, M.; et al. Altered TAOK2 activity causes autism-related neurodevelopmental and cognitive abnormalities through RhoA signaling. Mol. Psychiatry 2019, 24, 1329-1350. [CrossRef] [PubMed]

150. Fazel Darbandi, S.; Robinson Schwartz, S.E.; Qi, Q.; Catta-Preta, R.; Pai, E.L.-L.; Mandell, J.D.; Everitt, A.; Rubin, A.; Krasnoff, R.A.; Katzman, S.; et al. Neonatal Tbr1 Dosage Controls Cortical Layer 6 Connectivity. Neuron 2018, 100, 831-845.e7. [CrossRef] [PubMed]

151. Hevner, R.F.; Shi, L.; Justice, N.; Hsueh, Y.; Sheng, M.; Smiga, S.; Bulfone, A.; Goffinet, A.M.; Campagnoni, A.T.; Rubenstein, J.L. Tbr1 regulates differentiation of the preplate and layer 6. Neuron 2001, 29, 353-366. [CrossRef]

152. Huang, T.-N.; Yen, T.-L.; Qiu, L.R.; Chuang, H.-C.; Lerch, J.P.; Hsueh, Y.-P. Haploinsufficiency of autism causative gene Tbr1 impairs olfactory discrimination and neuronal activation of the olfactory system in mice. Mol. Autism 2019, 10, 5. [CrossRef]

153. Huang, T.-N.; Chuang, H.-C.; Chou, W.-H.; Chen, C.-Y.; Wang, H.-F.; Chou, S.-J.; Hsueh, Y.-P. Tbr1 haploinsufficiency impairs amygdalar axonal projections and results in cognitive abnormality. Nat. Neurosci. 2014, 17, 240-247. [CrossRef]

154. Huang, L.; Shum, E.Y.; Jones, S.H.; Lou, C.-H.; Dumdie, J.; Kim, H.; Roberts, A.J.; Jolly, L.A.; Espinoza, J.L.; Skarbrevik, D.M.; et al. A Upf3b-mutant mouse model with behavioral and neurogenesis defects. Mol. Psychiatry 2018, 23, 1773-1786. [CrossRef]

155. Zigler, J.S.; Hodgkinson, C.A.; Wright, M.; Klise, A.; Sundin, O.; Broman, K.W.; Hejtmancik, F.; Huang, H.; Patek, B.; Sergeev, Y.; et al. A Spontaneous missense mutation in branched chain keto acid dehydrogenase kinase in the rat affects both the central and peripheral nervous systems. PLoS ONE 2016, 11, e0160447. [CrossRef]

156. Kisko, T.M.; Braun, M.D.; Michels, S.; Witt, S.H.; Rietschel, M.; Culmsee, C.; Schwarting, R.K.W.; Wöhr, M. Cacna1c haploinsufficiency leads to pro-social $50-\mathrm{kHz}$ ultrasonic communication deficits in rats. Dis. Model. Mech. 2018, 11, dmm034116. [CrossRef]

157. Wöhr, M.; Willadsen, M.; Kisko, T.M.; Schwarting, R.K.W.; Fendt, M. Sex-dependent effects of Cacna1c haploinsufficiency on behavioral inhibition evoked by conspecific alarm signals in rats. Prog. Neuro-Psychopharmacol. Biol. Psychiatry 2020, 99, 109849. [CrossRef] [PubMed]

158. Scott, K.E.; Schormans, A.L.; Pacoli, K.Y.; De Oliveira, C.; Allman, B.L.; Schmid, S. Altered auditory processing, filtering, and reactivity in the Cntnap2 knock-out rat model for neurodevelopmental disorders. J. Neurosci. 2018, 38, 8588-8604. [CrossRef] [PubMed]

159. Thomas, A.M.; Schwartz, M.D.; Saxe, M.D.; Kilduff, T.S. Cntnap2 knockout rats and mice exhibit epileptiform activity and abnormal sleep-wake physiology. Sleep 2017, 40. [CrossRef] [PubMed]

160. Silva, A.I.; Haddon, J.E.; Ahmed Syed, Y.; Trent, S.; Lin, T.C.E.; Patel, Y.; Carter, J.; Haan, N.; Honey, R.C.; Humby, T.; et al. Cyfip1 haploinsufficient rats show white matter changes, myelin thinning, abnormal oligodendrocytes and behavioural inflexibility. Nat. Commun. 2019, 10, 3455. [CrossRef] [PubMed]

161. Asiminas, A.; Jackson, A.D.; Louros, S.R.; Till, S.M.; Spano, T.; Dando, O.; Bear, M.F.; Chattarji, S.; Hardingham, G.E.; Osterweil, E.K.; et al. Sustained correction of associative learning deficits after brief, early treatment in a rat model of Fragile X Syndrome. Sci. Transl. Med. 2019, 11. [CrossRef] [PubMed]

162. Hamilton, S.M.; Green, J.R.; Veeraragavan, S.; Yuva, L.; McCoy, A.; Wu, Y.; Warren, J.; Little, L.; Ji, D.; Cui, X.; et al. Fmr1 and Nlgn3 knockout rats: Novel tools for investigating autism spectrum disorders. Behav. Neurosci. 2014, 128, 103-109. [CrossRef] [PubMed]

163. Ruby, K.; Falvey, K.; Kulesza, R.J. Abnormal neuronal morphology and neurochemistry in the auditory brainstem of Fmr1 knockout rats. Neuroscience 2015, 303, 285-298. [CrossRef]

164. Engineer, C.T.; Rahebi, K.C.; Borland, M.S.; Buell, E.P.; Centanni, T.M.; Fink, M.K.; Im, K.W.; Wilson, L.G.; Kilgard, M.P. Degraded neural and behavioral processing of speech sounds in a rat model of Rett syndrome. Neurobiol. Dis. 2015, 83, 26-34. [CrossRef]

165. Wu, Y.; Zhong, W.; Cui, N.; Johnson, C.M.; Xing, H.; Zhang, S.; Jiang, C. Characterization of Rett Syndrome-like phenotypes in Mecp2-knockout rats. J. Neurodev. Disord. 2016, 8, 23. [CrossRef]

166. Kohl, C.; Riccio, O.; Grosse, J.; Zanoletti, O.; Fournier, C.; Schmidt, M.V.; Sandi, C. Hippocampal neuroligin-2 overexpression leads to reduced aggression and inhibited novelty reactivity in rats. PLOS ONE 2013, 8, e56871. [CrossRef] 
167. Thomas, A.M.; Schwartz, M.D.; Saxe, M.D.; Kilduff, T.S. Sleep/wake physiology and quantitative electroencephalogram analysis of the Neuroligin-3 knockout rat model of Autism Spectrum Disorder. Sleep 2017, 40. [CrossRef] [PubMed]

168. Esclassan, F.; Francois, J.; Phillips, K.G.; Loomis, S.; Gilmour, G. Phenotypic characterization of nonsocial behavioral impairment in neurexin $1 \alpha$ knockout rats. Behav. Neurosci. 2015, 129, 74-85. [CrossRef] [PubMed]

169. Rowley, P.A.; Guerrero-Gonzalez, J.; Alexander, A.L.; Yu, J.-P.J. Convergent microstructural brain changes across genetic models of Autism Spectrum Disorder-A pilot study. Psychiatry Res. Neuroimaging 2019, 283, 83-91. [CrossRef]

170. Ohmori, I.; Kawakami, N.; Liu, S.; Wang, H.; Miyazaki, I.; Asanuma, M.; Michiue, H.; Matsui, H.; Mashimo, T.; Ouchida, M. Methylphenidate improves learning impairments and hyperthermia-induced seizures caused by an Scn1a mutation. Epilepsia 2014, 55, 1558-1567. [CrossRef] [PubMed]

171. Modi, M.E.; Brooks, J.M.; Guilmette, E.R.; Beyna, M.; Graf, R.; Reim, D.; Schmeisser, M.J.; Boeckers, T.M.; O'Donnell, P.; Buhl, D.L. Hyperactivity and hypermotivation associated with increased striatal mGluR1 signaling in a Shank2 rat model of autism. Front. Mol. Neurosci. 2018, 11, 107. [CrossRef]

172. Harony-Nicolas, H.; Kay, M.; du Hoffmann, J.; Klein, M.E.; Bozdagi-Gunal, O.; Riad, M.; Daskalakis, N.P.; Sonar, S.; Castillo, P.E.; Hof, P.R.; et al. Oxytocin improves behavioral and electrophysiological deficits in a novel Shank3-deficient rat. Elife 2017, 6, e18904. [CrossRef]

173. Rannals, M.D.; Page, S.C.; Campbell, M.N.; Gallo, R.A.; Mayfield, B.; Maher, B.J. Neurodevelopmental models of transcription factor 4 deficiency converge on a common ion channel as a potential therapeutic target for Pitt Hopkins Syndrome. Rare Dis. 2016, 4, e1220468. [CrossRef]

174. Chi, O.Z.; Wu, C.C.; Liu, X.; Rah, K.H.; Jacinto, E.; Weiss, H.R. Restoration of normal cerebral oxygen consumption with rapamycin treatment in a rat model of autism-tuberous sclerosis. NeuroMol. Med. 2015, 17, 305-313. [CrossRef]

175. Waltereit, R.; Welzl, H.; Dichgans, J.; Lipp, H.P.; Schmidt, W.J.; Weller, M. Enhanced episodic-like memory and kindling epilepsy in a rat model of tuberous sclerosis. J. Neurochem. 2006, 96, 407-413. [CrossRef]

176. Dodge, A.; Peters, M.M.; Greene, H.E.; Dietrick, C.; Botelho, R.; Chung, D.; Willman, J.; Nenninger, A.W.; Ciarlone, S.; Kamath, S.G.; et al. Generation of a novel rat model of Angelman Syndrome with a complete Ube3a gene deletion. Autism Res. 2020, 13, 397-409. [CrossRef]

177. Li, J.; Ge, W. Zebrafish as a model for studying ovarian development: Recent advances from targeted gene knockout studies. Mol. Cell. Endocrinol. 2020, 507, 110778. [CrossRef] [PubMed]

178. Zon, L.I. Zebrafish: A new model for human disease. Genome Res. 1999, 9, 99-100. [PubMed]

179. Ahrens, M.B.; Orger, M.B.; Robson, D.N.; Li, J.M.; Keller, P.J. Whole-brain functional imaging at cellular resolution using light-sheet microscopy. Nat. Methods 2013, 10, 413-420. [CrossRef] [PubMed]

180. Rainboth, W. Inland fishes of India and adjacent countries. Rev. Fish Biol. Fish. 1994, 4, 135-136. [CrossRef]

181. Parichy, D.M. The natural history of model organisms: Advancing biology through a deeper understanding of zebrafish ecology and evolution. Elife 2015, 2015, e05635. [CrossRef] [PubMed]

182. Westerfield, M. The Zebrafish Book: A Guide for the Laboratory Use of Zebrafish. 2000. Available online: https://zfin.org/zf_info/zfbook/zfbk.html (accessed on 19 September 2020).

183. Meshalkina, D.; Kysil, E.; Warnick, J.E.; Demin, K. Adult zebrafish in CNS disease modeling: A tank that's half-full, not half-empty, and still filling. Lab Anim 2017, 46, 378-387. [CrossRef]

184. Lam, S.H.; Chua, H.L.; Gong, Z.; Lam, T.J.; Sin, Y.M. Development and maturation of the immune system in zebrafish, Danio rerio: A gene expression profiling, in situ hybridization and immunological study. Dev. Comp. Immunol. 2004, 28, 9-28. [CrossRef]

185. Patton, E.E.; Zon, L.I. The art and design of genetic screens: Zebrafish. Nat. Rev. Genet. 2001, 2, 956-966. [CrossRef]

186. Dooley, K.; Zon, L.I. Zebrafish: A model system for the study of human disease. Curr. Opin. Genet. Dev. 2000, 10, 252-256. [CrossRef]

187. Workman, A.D.; Charvet, C.J.; Clancy, B.; Darlington, R.B.; Finlay, B.L. Modeling transformations of neurodevelopmental sequences across mammalian species. J. Neurosci. 2013, 33, 7368-7383. [CrossRef]

188. Lumsden, A.; Krumlauf, R. Patterning the vertebrate neuraxis. Science 1996, 274, 1109-1115. [CrossRef] [PubMed]

189. Kimmel, C.B.; Ballard, W.W.; Kimmel, S.R.; Ullmann, B.; Schilling, T.F. Stages of embryonic development of the zebrafish. Dev. Dyn. 1995, 203, 253-310. [CrossRef] [PubMed] 
190. Guo, S. Using zebrafish to assess the impact of drugs on neural development and function. Expert Opin. Drug Discov. 2009, 4, 715-726. [CrossRef]

191. Mueller, T.; Vernier, P.; Wullimann, M.F. The adult central nervous cholinergic system of a neurogenetic model animal, the zebrafish Danio rerio. Brain Res. 2004, 1011, 156-169. [CrossRef] [PubMed]

192. Mueller, T.; Wullimann, M.F. An evolutionary interpretation of teleostean forebrain anatomy. Brain Behav. Evol. 2009, 74, 30-42. [CrossRef]

193. Mueller, T.; Dong, Z.; Berberoglu, M.A.; Guo, S. The dorsal pallium in zebrafish, Danio rerio (Cyprinidae, Teleostei). Brain Res. 2011, 1381, 95-105. [CrossRef] [PubMed]

194. Kozol, R.A. Prenatal neuropathologies in autism spectrum disorder and intellectual disability: The gestation of a comprehensive Zebrafish model. J. Dev. Biol. 2018, 6, 29. [CrossRef]

195. Bae, Y.K.; Kani, S.; Shimizu, T.; Tanabe, K.; Nojima, H.; Kimura, Y.; Shin-ichi, H.; Hibi, M. Anatomy of zebrafish cerebellum and screen for mutations affecting its development. Dev. Biol. 2009, 330, 406-426. [CrossRef]

196. Kani, S.; Bae, Y.K.; Shimizu, T.; Tanabe, K.; Satou, C.; Parsons, M.J.; Scott, E.; Higashijima, S.I.; Hibi, M. Proneural gene-linked neurogenesis in zebrafish cerebellum. Dev. Biol. 2010, 343, 1-17. [CrossRef]

197. Sudarov, A. Defining the role of cerebellar purkinje cells in autism spectrum disorders. Cerebellum 2013, 12, 950-955. [CrossRef]

198. Bauman, M.L.; Kemper, T.L. Neuroanatomic observations of the brain in autism: A review and future directions. Int. J. Dev. Neurosci. 2005, 23, 183-187. [CrossRef] [PubMed]

199. Jeong, J.W.; Tiwari, V.N.; Behen, M.E.; Chugani, H.T.; Chugani, D.C. In vivo detection of reduced purkinje cell fibers with diffusion MRI tractography in children with autistic spectrum disorders. Front. Hum. Neurosci. 2014, 8, 110. [CrossRef] [PubMed]

200. Rico, E.P.; Rosemberg, D.B.; Seibt, K.J.; Capiotti, K.M.; Da Silva, R.S.; Bonan, C.D. Zebrafish neurotransmitter systems as potential pharmacological and toxicological targets. Neurotoxicol. Teratol. 2011, 33, 608-617. [CrossRef] [PubMed]

201. Guissart, C.; Latypova, X.; Rollier, P.; Khan, T.N.; Stamberger, H.; McWalter, K.; Cho, M.T.; Kjaergaard, S.; Weckhuysen, S.; Lesca, G.; et al. Dual Molecular Effects of Dominant RORA Mutations Cause Two Variants of Syndromic Intellectual Disability with Either Autism or Cerebellar Ataxia. Am. J. Hum. Genet. 2018, 102, 744-759. [CrossRef] [PubMed]

202. Howe, K.; Clark, M.D.; Torroja, C.F.; Torrance, J.; Berthelot, C.; Muffato, M.; Collins, J.E.; Humphray, S.; McLaren, K.; Matthews, L.; et al. The zebrafish reference genome sequence and its relationship to the human genome. Nature 2013, 496, 498-503. [CrossRef]

203. Souza, B.R.; Tropepe, V. The role of dopaminergic signalling during larval zebrafish brain development: A tool for investigating the developmental basis of neuropsychiatric disorders. Rev. Neurosci. 2011, 22, 107-119. [CrossRef]

204. Yoshida, M.; Macklin, W.B. Oligodendrocyte development and myelination in GFP-transgenic zebrafish. J. Neurosci. Res. 2005, 81, 1-8. [CrossRef]

205. Lovett-Barron, M.; Andalman, A.S.; Allen, W.E.; Vesuna, S.; Kauvar, I.; Burns, V.M.; Deisseroth, K. Ancestral Circuits for the Coordinated Modulation of Brain State. Cell 2017, 171, 1411-1423.e17. [CrossRef]

206. Hisano, Y.; Ota, S.; Kawahara, A. Genome editing using artificial site-specific nucleases in zebrafish. Dev. Growth Differ. 2014, 56, 26-33. [CrossRef]

207. Nasevicius, A.; Ekker, S.C. Effective targeted gene “knockdown” in zebrafish. Nat. Genet. 2000, 26, $216-220$. [CrossRef]

208. Summerton, J.E. Invention and early history of morpholinos: From pipe dream to practical products. In Methods in Molecular Biology; Humana Press Inc.: Totowa, NJ, USA, 2017; Volume 1565, pp. 1-15.

209. Bill, B.R.; Petzold, A.M.; Clark, K.J.; Schimmenti, L.A.; Ekker, S.C. A primer for morpholino use in zebrafish. Zebrafish 2009, 6, 69-77. [CrossRef] [PubMed]

210. Eisen, J.S.; Smith, J.C. Controlling morpholino experiments: Don't stop making antisense. Development 2008, 135, 1735-1743. [CrossRef] [PubMed]

211. Stainier, D.Y.R.; Raz, E.; Lawson, N.D.; Ekker, S.C.; Burdine, R.D.; Eisen, J.S.; Ingham, P.W.; Schulte-Merker, S.; Yelon, D.; Weinstein, B.M.; et al. Guidelines for morpholino use in zebrafish. PLoS Genet. 2017, 13. [CrossRef] [PubMed] 
212. Wienholds, E.; van Eeden, F.; Kosters, M.; Mudde, J.; Plasterk, R.H.A.; Cuppen, E. Efficient target-selected mutagenesis in zebrafish. Genome Res. 2003, 13, 2700-2707. [CrossRef]

213. Kuroyanagi, M.; Katayama, T.; Imai, T.; Yamamoto, Y.; Shin-ichi, C.; Yoshiura, Y.; Ushijima, T.; Matsushita, T.; Fujita, M.; Nozawa, A.; et al. New approach for fish breeding by chemical mutagenesis: Establishment of TILLING method in fugu (Takifugu rubripes) with ENU mutagenesis. BMC Genomics 2013, 14. [CrossRef] [PubMed]

214. Doyon, Y.; McCammon, J.M.; Miller, J.C.; Faraji, F.; Ngo, C.; Katibah, G.E.; Amora, R.; Hocking, T.D.; Zhang, L.; Rebar, E.J.; et al. Heritable targeted gene disruption in zebrafish using designed zinc-finger nucleases. Nat. Biotechnol. 2008, 26, 702-708. [CrossRef] [PubMed]

215. Huang, P.; Xiao, A.; Zhou, M.; Zhu, Z.; Lin, S.; Zhang, B. Heritable gene targeting in zebrafish using customized TALENs. Nat. Biotechnol. 2011, 29, 699-700. [CrossRef]

216. Moreno-Mateos, M.A.; Vejnar, C.E.; Beaudoin, J.D.; Fernandez, J.P.; Mis, E.K.; Khokha, M.K.; Giraldez, A.J. CRISPRscan: Designing highly efficient sgRNAs for CRISPR-Cas9 targeting in vivo. Nat. Methods 2015, 12, 982-988. [CrossRef]

217. Vejnar, C.E.; Moreno-Mateos, M.A.; Cifuentes, D.; Bazzini, A.A.; Giraldez, A.J. Optimized CRISPR-Cas9 system for genome editing in zebrafish. Cold Spring Harb. Protoc. 2016, 2016, 856-870. [CrossRef]

218. Thyme, S.B.; Pieper, L.M.; Li, E.H.; Pandey, S.; Wang, Y.; Morris, N.S.; Sha, C.; Choi, J.W.; Herrera, K.J.; Soucy, E.R.; et al. Phenotypic Landscape of Schizophrenia-Associated Genes Defines Candidates and Their Shared Functions. Cell 2019, 177, 478-491.e20. [CrossRef]

219. Liu, X.; Hu, G.; Ye, J.; Ye, B.; Shen, N.; Tao, Y.; Zhang, X.; Fan, Y.; Liu, H.; Zhang, Z.; et al. De Novo ARID1B mutations cause growth delay associated with aberrant $\mathrm{Wnt} / \beta$-catenin signaling. Hum. Mutat. 2020, 41, 1012-1024. [CrossRef] [PubMed]

220. Ishibashi, M.; Manning, E.; Shoubridge, C.; Krecsmarik, M.; Hawkins, T.A.; Giacomotto, J.; Zhao, T.; Mueller, T.; Bader, P.I.; Cheung, S.W.; et al. Copy number variants in patients with intellectual disability affect the regulation of ARX transcription factor gene. Hum. Genet. 2015, 134, 1163-1182. [CrossRef] [PubMed]

221. Oksenberg, N.; Stevison, L.; Wall, J.D.; Ahituv, N. Function and regulation of AUTS2, a gene implicated in autism and human evolution. PLoS Genet. 2013, 9, e1003221. [CrossRef] [PubMed]

222. Ramachandran, K.V.; Hennessey, J.A.; Barnett, A.S.; Yin, X.; Stadt, H.A.; Foster, E.; Shah, R.A.; Yazawa, M.; Dolmetsch, R.E.; Kirby, M.L.; et al. Calcium influx through L-type CaV1.2 $\mathrm{Ca}^{2+}$ channels regulates mandibular development. J. Clin. Investig. 2013, 123, 1638-1646. [CrossRef] [PubMed]

223. Patowary, A.; Won, S.Y.; Oh, S.J.; Nesbitt, R.R.; Archer, M.; Nickerson, D.; Raskind, W.H.; Bernier, R.; Lee, J.E.; Brkanac, Z. Family-based exome sequencing and case-control analysis implicate CEP41 as an ASD gene. Transl. Psychiatry 2019, 9. [CrossRef] [PubMed]

224. Suls, A.; Jaehn, J.A.; Kecskés, A.; Weber, Y.; Weckhuysen, S.; Craiu, D.C.; Siekierska, A.; Djémie, T.; Afrikanova, T.; Gormley, P.; et al. De novo loss-of-function mutations in CHD2 cause a fever-sensitive myoclonic epileptic encephalopathy sharing features with dravet syndrome. Am. J. Hum. Genet. 2013, 93, 967-975. [CrossRef]

225. Bernier, R.; Golzio, C.; Xiong, B.; Stessman, H.A.; Coe, B.P.; Penn, O.; Witherspoon, K.; Gerdts, J.; Baker, C.; Vulto-van Silfhout, A.T.; et al. Disruptive CHD8 mutations define a subtype of autism early in development. Cell 2014, 158, 263-276. [CrossRef]

226. Sugathan, A.; Biagioli, M.; Golzio, C.; Erdin, S.; Blumenthal, I.; Manavalan, P.; Ragavendran, A.; Brand, H.; Lucente, D.; Miles, J.; et al. CHD8 regulates neurodevelopmental pathways associated with autism spectrum disorder in neural progenitors. Proc. Natl. Acad. Sci. USA 2014, 111, E4468-E4477. [CrossRef]

227. Turner, T.N.; Sharma, K.; Oh, E.C.; Liu, Y.P.; Collins, R.L.; Sosa, M.X.; Auer, D.R.; Brand, H.; Sanders, S.J.; Moreno-De-Luca, D.; et al. Loss of $\delta$-catenin function in severe autism. Nature 2015, 520, 51-56. [CrossRef]

228. Kim, O.H.; Cho, H.J.; Han, E.; Hong, T.I.; Ariyasiri, K.; Choi, J.H.; Hwang, K.S.; Jeong, Y.M.; Yang, S.Y.; Yu, K.; et al. Zebrafish knockout of Down syndrome gene, DYRK1A, shows social impairments relevant to autism. Mol. Autism 2017, 8. [CrossRef]

229. Hu, J.; Chen, L.; Yin, J.; Yin, H.; Huang, Y.; Tian, J. Hyperactivity, memory defects, and craniofacial abnormalities in zebrafish fmr1 mutant larvae. Behav. Genet. 2020, 50, 152-160. [CrossRef] [PubMed]

230. Kim, L.; He, L.; Maaswinkel, H.; Zhu, L.; Sirotkin, H.; Weng, W. Anxiety, hyperactivity and stereotypy in a zebrafish model of Fragile X Syndrome and Autism Spectrum Disorder. Prog. Neuro-Psychopharmacol. Biol. Psychiatry 2014, 55, 40-49. [CrossRef] [PubMed] 
231. Wu, Y.J.; Hsu, M.T.; Ng, M.C.; Amstislavskaya, T.G.; Tikhonova, M.A.; Yang, Y.L.; Lu, K.T. Fragile X mental retardation-1 knockout zebrafish shows precocious development in social behavior. Zebrafish 2017, 14, 438-443. [CrossRef] [PubMed]

232. Sicca, F.; Ambrosini, E.; Marchese, M.; Sforna, L.; Servettini, I.; Valvo, G.; Brignone, M.S.; Lanciotti, A.; Moro, F.; Grottesi, A.; et al. Gain-of-function defects of astrocytic Kir4.1 channels in children with Autism Spectrum Disorders and epilepsy. Sci. Rep. 2016, 6, 34325. [CrossRef]

233. Bögershausen, N.; Tsai, I.C.; Pohl, E.; Kiper, P.O.S.; Beleggia, F.; Ferda Percin, E.; Keupp, K.; Matchan, A.; Milz, E.; Alanay, Y.; et al. RAP1-mediated MEK/ERK pathway defects in Kabuki syndrome. J. Clin. Investig. 2015, 125, 3585-3599. [CrossRef]

234. Van Laarhoven, P.M.; Neitzel, L.R.; Quintana, A.M.; Geiger, E.A.; Zackai, E.H.; Clouthier, D.E.; Artinger, K.B.; Ming, J.E.; Shaikh, T.H. Kabuki syndrome genes KMT2D and KDM6A: Functional analyses demonstrate critical roles in craniofacial, heart and brain development. Hum. Mol. Genet. 2015, 24, 4443-4453. [CrossRef]

235. Leong, W.Y.; Lim, Z.H.; Korzh, V.; Pietri, T.; Goh, E.L.K. Methyl-CpG binding protein 2 (Mecp2) regulates sensory function through Sema5b and Robo2. Front. Cell. Neurosci. 2015, 9. [CrossRef]

236. Pietri, T.; Roman, A.-C.; Guyon, N.; Romano, S.A.; Washbourne, P.; Moens, C.B.; de Polavieja, G.G.; Sumbre, G. The first mecp2-null zebrafish model shows altered motor behaviors. Front. Neural Circuits 2013, 7, 118. [CrossRef]

237. Van Der Vaart, M.; Svoboda, O.; Weijts, B.G.; Espín-Palazón, R.; Sapp, V.; Pietri, T.; Bagnat, M.; Muotri, A.R.; Traver, D. Mecp2 regulates tnfa during zebrafish embryonic development and acute inflammation. DMM Dis. Model. Mech. 2017, 10, 1439-1451. [CrossRef]

238. Elsen, G.E.; Choi, L.Y.; Prince, V.E.; Ho, R.K. The autism susceptibility gene met regulates zebrafish cerebellar development and facial motor neuron migration. Dev. Biol. 2009, 335, 78-92. [CrossRef]

239. Blanchet, P.; Bebin, M.; Bruet, S.; Cooper, G.M.; Thompson, M.L.; Duban-Bedu, B.; Gerard, B.; Piton, A.; Suckno, S.; Deshpande, C.; et al. MYT1L mutations cause intellectual disability and variable obesity by dysregulating gene expression and development of the neuroendocrine hypothalamus. PLoS Genet. 2017, 13. [CrossRef] [PubMed]

240. Miller, A.C.; Voelker, L.H.; Shah, A.N.; Moens, C.B. Neurobeachin is required postsynaptically for electrical and chemical synapse formation. Curr. Biol. 2015, 25, 16-28. [CrossRef] [PubMed]

241. Ruzzo, E.K.; Pérez-Cano, L.; Jung, J.Y.; Wang, L.K.; Kashef-Haghighi, D.; Hartl, C.; Singh, C.; Xu, J.; Hoekstra, J.N.; Leventhal, O.; et al. Inherited and de novo genetic risk for autism impacts shared networks. Cell 2019, 178, 850-866.e26. [CrossRef] [PubMed]

242. Ribeiro, D.; Nunes, A.R.; Gliksberg, M.; Anbalagan, S.; Levkowitz, G.; Oliveira, R.F. Oxytocin receptor signalling modulates novelty recognition but not social preference in zebrafish. J. Neuroendocrinol. 2020, 32, e12834. [CrossRef]

243. Vecchia, E.D.; Di Donato, V.; Young, A.M.J.; Del Bene, F.; Norton, W.H.J. Reelin signaling controls the preference for social novelty in zebrafish. Front. Behav. Neurosci. 2019, 13, 214. [CrossRef]

244. Plaster, N.; Sonntag, C.; Schilling, T.F.; Hammerschmidt, M. REREa/Atrophin-2 interacts with histone deacetylase and Fgf8 signaling to regulate multiple processes of zebrafish development. Dev. Dyn. 2007, 236, 1891-1904. [CrossRef]

245. Kozol, R.A.; Cukier, H.N.; Zou, B.; Mayo, V.; De Rubeis, S.; Cai, G.; Griswold, A.J.; Whitehead, P.L.; Haines, J.L.; Gilbert, J.R.; et al. Two knockdown models of the autism genes SYNGAP1 and SHANK3 in zebrafish produce similar behavioral phenotypes associated with embryonic disruptions of brain morphogenesis. Hum. Mol. Genet. 2015, 24, 4006-4023. [CrossRef]

246. Liu, C.X.; Li, C.Y.; Hu, C.C.; Wang, Y.; Lin, J.; Jiang, Y.H.; Li, Q.; Xu, X. CRISPR/Cas9-induced shank3b mutant zebrafish display autism-like behaviors. Mol. Autism 2018, 9. [CrossRef]

247. Masai, I.; Lele, Z.; Yamaguchi, M.; Komori, A.; Nakata, A.; Nishiwaki, Y.; Wada, H.; Tanaka, H.; Nojima, Y.; Hammerschmidt, M.; et al. N-cadherin mediates retinal lamination, maintenance of forebrain compartments and patterning of retinal neurites. Development 2003, 130, 2479-2494. [CrossRef]

248. Xiao, T.; Roeser, T.; Staub, W.; Baier, H. A GFP-based genetic screen reveals mutations that disrupt the architecture of the zebrafish retinotectal projection. Development 2005, 132, 2955-2967. [CrossRef]

249. Xi, Y.; Yu, M.; Godoy, R.; Hatch, G.; Poitras, L.; Ekker, M. Transgenic zebrafish expressing green fluorescent protein in dopaminergic neurons of the ventral diencephalon. Dev. Dyn. 2011, 240, 2539-2547. [CrossRef] [PubMed] 
250. dal Maschio, M.; Donovan, J.C.; Helmbrecht, T.O.; Baier, H. Linking Neurons to Network Function and Behavior by Two-Photon Holographic Optogenetics and Volumetric Imaging. Neuron 2017, 94, 774-789.e5. [CrossRef] [PubMed]

251. Higashijima, S.I.; Masino, M.A.; Mandel, G.; Fetcho, J.R. Engrailed-1 expression marks a primitive class of inhibitory spinal interneuron. J. Neurosci. 2004, 24, 5827-5839. [CrossRef] [PubMed]

252. Choi, J.; Dong, L.; Ahn, J.; Dao, D.; Hammerschmidt, M.; Chen, J.N. FoxH1 negatively modulates flk1 gene expression and vascular formation in zebrafish. Dev. Biol. 2007, 304, 735-744. [CrossRef]

253. Satou, C.; Kimura, Y.; Hirata, H.; Suster, M.L.; Kawakami, K.; Higashijima, S.I. Transgenic tools to characterize neuronal properties of discrete populations of zebrafish neurons. Development 2013, 140, 3927-3931. [CrossRef]

254. Bernardos, R.L.; Raymond, P.A. GFAP transgenic zebrafish. Gene Expr. Patterns 2006, 6, 1007-1013. [CrossRef]

255. McLean, D.L.; Fan, J.; Higashijima, S.I.; Hale, M.E.; Fetcho, J.R. A topographic map of recruitment in spinal cord. Nature 2007, 446, 71-75. [CrossRef]

256. Higashijima, S.I.; Hotta, Y.; Okamoto, H. Visualization of cranial motor neurons in live transgenic zebrafish expressing green fluorescent protein under the control of the Islet-1 promoter/enhancer. J. Neurosci. 2000, 20, 206-218. [CrossRef]

257. Heffer, A.; Marquart, G.D.; Aquilina-Beck, A.; Saleem, N.; Burgess, H.A.; Dawid, I.B. Generation and characterization of Kctd15 mutations in zebrafish. PLoS ONE 2017, 12. [CrossRef]

258. Spiró, Z.; Koh, A.; Tay, S.; See, K.; Winkler, C. Transcriptional enhancement of Smn levels in motoneurons is crucial for proper axon morphology in zebrafish. Sci. Rep. 2016, 6. [CrossRef]

259. Obholzer, N.; Wolfson, S.; Trapani, J.G.; Mo, W.; Nechiporuk, A.; Busch-Nentwich, E.; Seiler, C.; Sidi, S.; Söllner, C.; Duncan, R.N.; et al. Vesicular glutamate transporter 3 is required for synaptic transmission in zebrafish hair cells. J. Neurosci. 2008, 28, 2110-2118. [CrossRef] [PubMed]

260. Blader, P.; Plessy, C.; Strähle, U. Multiple regulatory elements with spatially and temporally distinct activities control neurogenin1 expression in primary neurons of the zebrafish embryo. Mech. Dev. 2003, 120, 211-218. [CrossRef]

261. Shin, J.; Park, H.C.; Topczewska, J.M.; Madwsley, D.J.; Appel, B. Neural cell fate analysis in zebrafish using olig2 BAC transgenics. Methods Cell Sci. 2003, 25, 7-14. [CrossRef]

262. Lillesaar, C.; Stigloher, C.; Tannhäuser, B.; Wullimann, M.F.; Bally-Cuif, L. Axonal projections originating from raphe serotonergic neurons in the developing and adult Zebrafish, Danio Rerio, using transgenics to visualize Raphe-specific pet1 expression. J. Comp. Neurol. 2009, 512, 158-182. [CrossRef] [PubMed]

263. Chen, A.; Chiu, C.N.; Mosser, E.A.; Kahn, S.; Spence, R.; Prober, D.A. QRFP and its receptors regulate locomotor activity and sleep in zebrafish. J. Neurosci. 2016, 36, 1823-1840. [CrossRef]

264. Wada, N.; Javidan, Y.; Nelson, S.; Carney, T.J.; Kelsh, R.N.; Schilling, T.F. Hedgehog signaling is required for cranial neural crest morphogenesis and chondrogenesis at the midline in the zebrafish skull. Development 2005, 132, 3977-3988. [CrossRef]

265. Takechi, M.; Hamaoka, T.; Kawamura, S. Fluorescence visualization of ultraviolet-sensitive cone photoreceptor development in living zebrafish. FEBS Lett. 2003, 553, 90-94. [CrossRef]

266. Wen, L.; Wei, W.; Gu, W.; Huang, P.; Ren, X.; Zhang, Z.; Zhu, Z.; Lin, S.; Zhang, B. Visualization of monoaminergic neurons and neurotoxicity of MPTP in live transgenic zebrafish. Dev. Biol. 2008, 314, 84-92. [CrossRef]

267. Ando, H.; Sato, T.; Ito, T.; Yamamoto, J.; Sakamoto, S.; Nitta, N.; Asatsuma-Okumura, T.; Shimizu, N.; Mizushima, R.; Aoki, I.; et al. Cereblon Control of Zebrafish Brain Size by Regulation of Neural Stem Cell Proliferation. iScience 2019, 15, 95-108. [CrossRef]

268. Liu, T.; Shi, Y.; Chan, M.T.V.; Peng, G.; Zhang, Q.; Sun, X.; Zhu, Z.; Xie, Y.; Sham, K.W.Y.; Li, J.; et al. Developmental protein kinase $C$ hyper-activation results in microcephaly and behavioral abnormalities in zebrafish. Transl. Psychiatry 2018, 8. [CrossRef]

269. Pilorge, M.; Fassier, C.; Le Corronc, H.; Potey, A.; Bai, J.; De Gois, S.; Delaby, E.; Assouline, B.; Guinchat, V.; Devillard, F.; et al. Genetic and functional analyses demonstrate a role for abnormal glycinergic signaling in autism. Mol. Psychiatry 2016, 21, 936-945. [CrossRef] [PubMed]

270. Baronio, D.; Puttonen, H.A.J.; Sundvik, M.; Semenova, S.; Lehtonen, E.; Panula, P. Embryonic exposure to valproic acid affects the histaminergic system and the social behaviour of adult zebrafish (Danio rerio). Br. J. Pharmacol. 2018, 175, 797-809. [CrossRef] [PubMed] 
271. James, D.M.; Kozol, R.A.; Kajiwara, Y.; Wahl, A.L.; Storrs, E.C.; Buxbaum, J.D.; Klein, M.; Moshiree, B.; Dallman, J.E. Intestinal dysmotility in a zebrafish (Danio rerio) shank3a;shank3b mutant model of autism. Mol. Autism 2019, 10. [CrossRef] [PubMed]

272. Lee, S.; Chun, H.S.; Lee, J.; Park, H.J.; Kim, K.T.; Kim, C.H.; Yoon, S.; Kim, W.K. Plausibility of the zebrafish embryos/larvae as an alternative animal model for autism: A comparison study of transcriptome changes. PLOS ONE 2018, 13. [CrossRef]

273. Campbell, P.D.; Granato, M. Zebrafish as a tool to study schizophrenia-associated copy number variants. DMM Dis. Model. Mech. 2020, 13. [CrossRef]

274. Brustein, E.; Saint-Amant, L.; Buss, R.R.; Chong, M.; McDearmid, J.R.; Drapeau, P. Steps during the development of the zebrafish locomotor network. J. Physiol. Paris 2003, 97, 77-86. [CrossRef]

275. Valente, A.; Huang, K.-H.; Portugues, R.; Engert, F. Ontogeny of classical and operant learning behaviors in zebrafish. Learn. Mem. 2012, 19, 170-177. [CrossRef]

276. Jain, R.A.; Wolman, M.A.; Marsden, K.C.; Nelson, J.C.; Shoenhard, H.; Echeverry, F.A.; Szi, C.; Bell, H.; Skinner, J.; Cobbs, E.N.; et al. A Forward Genetic Screen in Zebrafish Identifies the G-Protein-Coupled Receptor CaSR as a Modulator of Sensorimotor Decision Making. Curr. Biol. 2018, 28, 1357-1369.e5. [CrossRef]

277. Gleason, M.R.; Nagiel, A.; Jamet, S.; Vologodskaia, M.; López-Schier, H.; Hudspeth, A.J. The transmembrane inner ear (Tmie) protein is essential for normal hearing and balance in the zebrafish. Proc. Natl. Acad. Sci. USA 2009, 106, 21347-21352. [CrossRef]

278. Low, S.E.; Woods, I.G.; Lachance, M.; Ryan, J.; Schier, A.F.; Saint-Amant, L. Touch responsiveness in zebrafish requires voltage-gated calcium channel 2.1b. J. Neurophysiol. 2012, 108, 148-159. [CrossRef]

279. Mathuru, A.S.; Kibat, C.; Cheong, W.F.; Shui, G.; Wenk, M.R.; Friedrich, R.W.; Jesuthasan, S. Chondroitin fragments are odorants that trigger fear behavior in fish. Curr. Biol. 2012, 22, 538-544. [CrossRef] [PubMed]

280. Speedie, N.; Gerlai, R. Alarm substance induced behavioral responses in zebrafish (Danio rerio). Behav. Brain Res. 2008, 188, 168-177. [CrossRef] [PubMed]

281. Mahabir, S.; Chatterjee, D.; Buske, C.; Gerlai, R. Maturation of shoaling in two zebrafish strains: A behavioral and neurochemical analysis. Behav. Brain Res. 2013, 247, 1-8. [CrossRef] [PubMed]

282. Qin, M.; Wong, A.; Seguin, D.; Gerlai, R. Induction of social behavior in zebrafish: Live versus computer animated fish as stimuli. Zebrafish 2014, 11, 185-197. [CrossRef]

283. Babin, P.J.; Goizet, C.; Raldúa, D. Zebrafish models of human motor neuron diseases: Advantages and limitations. Prog. Neurobiol. 2014, 118, 36-58. [CrossRef]

284. Cassar, S.; Adatto, I.; Freeman, J.L.; Gamse, J.T.; Iturria, I.; Lawrence, C.; Muriana, A.; Peterson, R.T.; Van Cruchten, S.; Zon, L.I. Use of Zebrafish in Drug Discovery Toxicology. Chem. Res. Toxicol. 2020, 33, 95-118. [CrossRef]

285. Dwivedi, S.; Medishetti, R.; Rani, R.; Sevilimedu, A.; Kulkarni, P.; Yogeeswari, P. Larval zebrafish model for studying the effects of valproic acid on neurodevelopment: An approach towards modeling autism. J. Pharmacol. Toxicol. Methods 2019, 95, 56-65. [CrossRef]

286. Lynch, M.; Force, A. The probability of duplicate gene preservation by subfunctionalization. Genetics 2000, 154, 459-473.

287. Pereira, M.; Birtele, M.; Rylander Ottosson, D. Direct reprogramming into interneurons: Potential for brain repair. Cell. Mol. Life Sci. 2019, 76, 3953-3967. [CrossRef]

288. Haapaniemi, E.; Botla, S.; Persson, J.; Schmierer, B.; Taipale, J. CRISPR-Cas9 genome editing induces a p53-mediated DNA damage response. Nat. Med. 2018, 24, 927-930. [CrossRef]

289. Ihry, R.J.; Worringer, K.A.; Salick, M.R.; Frias, E.; Ho, D.; Theriault, K.; Kommineni, S.; Chen, J.; Sondey, M.; Ye, C.; et al. p53 inhibits CRISPR-Cas9 engineering in human pluripotent stem cells. Nat. Med. 2018, 24, 939-946. [CrossRef] [PubMed]

290. Meijboom, F.L.B.; Kostrzewa, E.; Leenaars, C.H.C. Joining forces: The need to combine science and ethics to address problems of validity and translation in neuropsychiatry research using animal models. Philos. Ethics Humanit. Med. 2020, 15, 1. [CrossRef] [PubMed]

291. DeGrazia, D.; Sebo, J. Necessary conditions for morally responsible animal research. Cambridge Q. Healthc. Ethics 2015, 24, 420-430. [CrossRef] [PubMed]

292. Wong, C.H.; Siah, K.W.; Lo, A.W. Estimation of clinical trial success rates and related parameters. Biostatistics 2019, 20, 273-286. [CrossRef] 
293. Freires, I.A.; de Sardi, J.C.O.; de Castro, R.D.; Rosalen, P.L. Alternative animal and non-animal models for drug discovery and development: Bonus or burden? Pharm. Res. 2017, 34, 681-686. [CrossRef]

294. Bovenkerk, B.; Kaldewaij, F. The use of animal models in behavioural neuroscience research. Curr. Top. Behav. Neurosci. 2015, 19, 17-46.

295. Kilkenny, C.; Browne, W.J.; Cuthill, I.C.; Emerson, M.; Altman, D.G. Improving bioscience research reporting: The ARRIVE guidelines for reporting animal research. PLoS Biol. 2010, 8, e1000412. [CrossRef]

296. Smith, A.J.; Clutton, R.E.; Lilley, E.; Hansen, K.E.A.; Brattelid, T. PREPARE: Guidelines for planning animal research and testing. Lab. Anim. 2018, 52, 135-141. [CrossRef]

Publisher's Note: MDPI stays neutral with regard to jurisdictional claims in published maps and institutional affiliations.

(C) 2020 by the authors. Licensee MDPI, Basel, Switzerland. This article is an open access article distributed under the terms and conditions of the Creative Commons Attribution (CC BY) license (http://creativecommons.org/licenses/by/4.0/). 